Article

\title{
Triatoma rosai sp. nov. (Hemiptera, Triatominae): A New Species of Argentinian Chagas Disease Vector Described Based on Integrative Taxonomy
}

\author{
Kaio Cesar Chaboli Alevi ${ }^{1,2,+}\left(\mathbb{D}\right.$, Jader de Oliveira ${ }^{1,+}\left(\mathbb{D}\right.$, Ariane Cristina Caris Garcia ${ }^{2}(\mathbb{D}$, \\ Daniel Cesaretto Cristal ${ }^{1}$, Luiza Maria Grzyb Delgado ${ }^{2}$, Isadora de Freitas Bittinelli ${ }^{2}$, \\ Yago Visinho dos Reis ${ }^{2}$, Amanda Ravazi ${ }^{2}$, Ana Beatriz Bortolozo de Oliveira ${ }^{3}$, \\ Cleber Galvão ${ }^{4, *(D)}$, Maria Tercília Vilela de Azeredo-Oliveira ${ }^{3, \ddagger}$ and Fernanda Fernandez Madeira $^{3, \ddagger}$ \\ 1 Laboratório de Parasitologia, Faculdade de Ciências Farmacêuticas, Universidade Estadual Paulista “Júlio \\ de Mesquita Filho" (UNESP), Rodovia Araraquara-Jaú km 1, 14801-902 Araraquara, SP, Brazil; \\ kaiochaboli@hotmail.com (K.C.C.A.); jdr.oliveira@hotmail.com (J.d.O.); daniel.cristal@hotmail.com (D.C.C.) \\ Instituto de Biociências de Botucatu, Universidade Estadual Paulista “Júlio de Mesquita Filho" (UNESP), \\ Rua Dr. Antônio Celso Wagner Zanin, 250, Distrito de Rubião Junior, 18618-689 Botucatu, SP, Brazil; \\ ariane.garcia@outlook.com (A.C.C.G.); uiza_grzyb.1998@hotmail.com (L.M.G.D.); \\ isadora_bittinelli@hotmail.com (I.d.F.B.); yagoreis@outlook.com.br (Y.V.d.R.); \\ amandaravazi95@gmail.com (A.R.) \\ 3 Laboratório de Biologia Celular, Instituto de Biociências, Universidade Estadual Paulista “Júlio de Mesquita \\ Filho" (UNESP), Letras e Ciências Exatas, Rua Cristóvão Colombo 2265, 15054-000 São José do Rio Preto, SP, \\ Brazil; anabbortolozo@gmail.com (A.B.B.d.O.); tercilia.vilela@unesp.br (M.T.V.d.A.-O.); \\ fernanda.bio56@hotmail.com (F.F.M.) \\ 4 Laboratório Nacional e Internacional de Referência em Taxonomia de Triatomíneos, \\ Instituto Oswaldo Cruz (FIOCRUZ), Av. Brazil 4365, Pavilhão Rocha Lima, sala 505, \\ 21040-360 Rio de Janeiro, RJ, Brazil \\ * Correspondence: clebergalvao@gmail.com \\ + Co-first authorship. \\ $\ddagger$ Co-last authorship.
}

Zoo Bank: http://www.zoobank.org/NomenclaturalActs/e23b86e9-d101-4e8e-960304a48422259e updates

Received: 22 September 2020; Accepted: 15 October 2020; Published: 26 November 2020

Simple Summary: Although all triatomines are potential vectors of Chagas' disease, there are species with greater or lesser vectorial importance. Therefore, the correct identification of triatomines species is essential for the vector control programs. In general, triatomines are identified by external morphological characters. However, some species are very similar or even morphologically identical, being important the use of complementary analyses for the correct identification of species. For this reason, this study focused on the use of morphological, morphometric, molecular data, and experimental crosses to describe Triatoma rosai sp. nov., a new species of Argentinian Chagas disease vector. Significant morphological and morphometric differences, associated with phylogenetic support and high mortality rate of the hybrids made it possible to confirm the specific status of T. rosai sp. nov., emphasizing the importance of integrative analyses for the taxonomy of triatomines.

Abstract: Chagas disease is the most prevalent neglected tropical disease in the Americas and makes an important contribution to morbidity and mortality rates in countries where it is endemic since 30 to $40 \%$ of patients develop cardiac diseases, gastrointestinal disorders, or both. In this paper, a new species of the genus Triatoma is described based on specimens collected in the Department San Miguel, Province of Corrientes, Argentina. Triatoma rosai sp. nov. is closely related to T. sordida (Stål, 1859), and was characterized based on integrative taxonomy using morphological, morphometric, molecular data, and experimental crosses. These analyses, combined with data from the literature (cytogenetics, 
electrophoresis pattern, molecular analyses, cuticular hydrocarbons pattern, geometric morphometry, cycle, and average time of life as well as geographic distribution) confirm the specific status of T. rosai sp. nov. Natural Trypanosoma cruzi infection, coupled with its presence mostly in peridomestic habitats, indicates that this species can be considered as an important Chagas disease vector from Argentina.

Keywords: triatomines; morphology; morphometry; molecular; experimental crosses; Chagas disease

\section{Introduction}

Chagas disease is the most prevalent neglected tropical disease in the Americas [1] and makes an important contribution to morbidity and mortality rates in countries where it is endemic $[2,3]$ since 30 to $40 \%$ of patients develop cardiac diseases, gastrointestinal disorders, or both [2]. It is estimated that 8 million people worldwide are infected by Trypanosoma cruzi (Chagas, 1909) (Kinetoplastida, Trypanosomatidae) (etiologic agent of Chagas disease) [3] and about 70 million people are living in areas with contamination risk [4], causing incapacity in infected individuals and more than 10,000 deaths per year [3,4].

Although there are several forms of contamination-organ transplantation of an infected donor, laboratory accidents, ingestion of contaminated food or liquids (sugarcane, acai, and raw meat), congenital (vertically between mother and child), or can happen through blood transfusion [5]-vectorial transmission by triatomines (Hemiptera, Triatominae) is the most important from an epidemiological point of view [3]. Thus, vector control remains the most useful method to prevent infection [3].

Currently, there are 154 species of triatomines described, grouped into 18 genera and five tribes [6]. Although there are species with a greater or lesser degree of importance in the transmission of Chagas disease, all triatomines, of both sexes and at any stage of development after hatching, are considered as potential vectors of this disease described more than 110 years ago $[7,8]$.

Triatoma sordida (Stål, 1859) (Hemiptera, Triatominae) is an endemic species in South America, distributed in Brazil, Argentina, Bolivia, Paraguay, and Uruguay, in the Atlantic forest, Caatinga, Cerrado, Chaco, and Pantanal biomes [9-11]. The taxonomic history of this species has been discussed since the 1960s when Abalos and Wygodzinsky [12] observed morphological variation among T. sordida populations from Santiago del Estero (northeastern Argentina). Subsequently, Actis et al. [13] evaluated the electrophoretic profiles of hemolymph proteins among Argentinean sylvatic samples with domestic specimens from Brazil and significant differences were observed. However, these wild populations of T. sordida from Argentina were described as T. garciabesi Carcavallo et al., 1967 [14]. After 12 years, this species was synonymized with T. sordida [8] and based on differences in their morphology, isoenzymes, and chromosomal characteristics were once again validated as T. garciabesi [15]. Noireau et al. [16] also observed a high genetic distance between T. sordida from Bolivia and considered the occurrence of the phenomenon of cryptic speciation for the first time. However, Panzera et al. [17] showed that one of the populations used by Noireau et al. [16] was T. garciabesi and not T. sordida.

Although these cases of "intraspecific variation" (which were interspecific [17]) have been performed incorrectly, intraspecific polymorphisms have been reported among populations of T. sordida from Brazil, Argentina, and Bolivia: Panzera et al. [17,18] based on chromosomal (constitutive heterochromatin pattern and FISH with a $45 \mathrm{~S}$ rDNA probe) and molecular data (mitochondrial gene COI) observed differences between these populations and suggested the existence of at least two possible different species associated with T. sordida (T sordida sensu stricto), namely T. sordida Argentina and T. sordida La Paz (differences confirmed by the cuticular hydrocarbons pattern [19]). Morphometric analyses also differentiated T. sordida from Argentina and the specimens from Brazil and Bolivia 
and emphasized the importance of additional studies to confirm the specific validity of the new $\operatorname{taxon}(\mathrm{s})[20]$.

Thus, based on several analyses based on integrative taxonomy (morphological, morphometric, molecular data and experimental crosses), as well as information from the literature (cytogenetics, electrophoresis pattern, molecular analyses, cuticular hydrocarbons pattern, geometric morphometry, cycle and average time of life as well as geographic distribution) that support the specific status of T. sordida from Argentina as a new taxon, we describe Triatoma rosai sp. nov.

\section{Materials and Methods}

\subsection{Sampling}

We examined specimens from Department San Miguel, Province of Corrientes, Argentina, characterized initially as T. sordida using the taxonomic key for the genus Triatoma Laporte, 1832 published by Lent and Wygodzinsky [8]. All studied species were kept alive at the Triatominae Insectarium of the São Paulo State University "Julio de Mesquita Filho", School of Pharmaceutical Sciences, Araraquara, São Paulo, Brazil.

\subsection{Morphological Identification and Description}

The description of T. rosai sp. nov. included 7 males and 7 females previously characterized as T. sordida (based on the dichotomous key by Lent and Wygodzinsky [8]). Triatoma rosai sp. nov. was compared with 9 male and 9 female specimens of T. sordida from Riacho dos Machados, Minas Gerais, Brazil (MG/Brazil) deposited in the Dr. Jose Maria Soares Barata Triatominae Collection (CTJMSB) of the São Paulo State University “Julio de Mesquita Filho", School of Pharmaceutical Sciences, Araraquara, São Paulo, Brazil.

\subsection{Morphological Studies in Scanning Electron Microscopy}

For the comparative morphological study, 2 males and 2 females of T. rosai sp. nov. and 2 males and 2 females of T. sordida (MG/Brazil) from Araraquara Triatominae Colony (CTA) were used. For morphological characterization of the triatomines in Scanning Electron Microscope (SEM) (according to Rosa et al. [21]), four individuals of each locality were used, emphasizing the study of the pronotum, scutellum, as well as female external genitalia. For this study, the insects were cleaned in ultrasonic devices, dehydrated in graded series of alcohol, oven-dried at $45^{\circ} \mathrm{C}$ for $20 \mathrm{~min}$, and then fixed in small aluminum cylinders with colorless enamel. Afterward, they were metalized by sputtering for two minutes with $10 \mathrm{~mA}$ of power. After the metallization process, the samples were analyzed and photographed on the Topcon SM-300 SEM (Digital, Hasunuma-cho, Tokyo, Japan).

\subsection{Morphological Studies in Optical Microscopy}

For the comparative morphological study of T. rosai sp. nov. and T. sordida we used images of the male's head, pronotum, and genitalia. For optical microscopy (OM), adult specimens of T. rosai sp. nov. (3 males and 3 females) and of T. sordida (MG/Brazil) ( 3 males and 3 females) were used. The analyses were performed using the Leica MZ APO Stereoscope Microscope (Digital, Wetzlar, Germany) with the Motic Images Advanced 3.2 plus image analysis system coupled.

\subsection{Morphometric Studies}

For measurement analyses, adult specimens of T. rosai sp. nov. (7 males and 7 females), and T. sordida (MG/Brazil) (9 males and 9 females) were used. The measurements of the head, thorax, abdomen, pronotum, and scutellum were performed using the Leica MZ APO Stereoscope Microscope with the Motic Images Advanced 3.2 plus image analysis system coupled. The data obtained were organized in the Excel $2007^{\circledR}$ spreadsheet software and presented as a table. The measurements of the thorax 
and abdomen parameters were statistically analyzed in the GraphPad Prism program version 7 for Windows, using Welch's $t$-test.

\subsection{Molecular Phylogeny and Genetic Distance}

Five specimens of T. sordida (T. sordida sensu stricto) (Brazil: Posse/Goiás and Seabra/Bahia), T. sordida La Paz (Bolivia: La Paz), and T. rosai sp. nov., were used for molecular analyses. For DNA extraction, using the DNeasy Blood and Tissue kit (QIAGEN ${ }^{\circledR}$, Hilden, Germany), one or two legs were placed in a $1.5 \mathrm{~mL}$ microtube, dipped into liquid nitrogen, and ground to powder. A 561-bp fragment of the mitochondrial (mt) cytochrome b gene (cyt b) and a 798-pb fragment of the nuclear Internal Transcribed Spacer-1 gene (ITS-1) were polymerase chain reaction (PCR) amplified as described in Monteiro et al. [22] and Tartarotti and Ceron [23], respectively. Amplicons were purified using a GFX PCR DNA \& Gel Band kit (GE Healthcare and Life Technology ${ }^{\circledR}$, Chicago, IL, USA) and both strands were subjected to Sanger sequencing reactions (ABI Prism ${ }^{\circledR}$ BigDye ${ }^{\circledR}$ Terminator v.3.1 Cycle Sequencing Kit, Applied Biosystems, Foster City, CA, USA) and run on an ABI 3730 sequencer. The sequences of all individuals were analyzed by using BioEdit Alignment Editor 7.0.5.3 [24] and a consensus sequence was obtained for each DNA segment. Sequences from other Brazilian localities (MG and MS), T. garciabesi, T. guasayana Wygodzinsky and Abalos, 1949 and Panstrongylus megistus (Burmeister, 1835) available on GenBank were also added to the alignment (Table 1). The sequences were aligned using the ClustalW Multiple Alignment tool [25]. Using the MEGA software (Molecular Evolutionary Genetics Analysis) v.6 [26] we constructed a genetic distance matrix using the Kimura-2 parameter distance model for estimation of evolutionary divergence between sequences of the cyt $b$ gene.

For the Bayesian inference, we combined unpublished and GenBank sequences (Table 1). All sequences used were submitted to the MEGA X program [27] and aligned by the Muscle method [28]. The alignments of each molecular marker (COI, Cyt b, 28S, 16S, and ITS-1) were concatenated by name using Seaview 4 software [29], posteriorly being converted on Mesquite program [30]. The data were partitioned for each marker, with the best-fit models of nucleotide substitution (lowest Akaike Information Criterion value) for the phylogenetic reconstruction determined by jModelTest 2 program [31], for each of them: HKY + G for 16S, HKY + I + G for Cyt b, HKY for ITS-1, GTR for $28 \mathrm{~S}$, and GTR + G for COI. A Bayesian phylogenetic tree for the complete data set of concatenated sequences was inferred in MrBayes 3.2 [32]. The trees were sampled every 1,000 generations, for a total of 100 million generations, in two independent runs and with a burn-in of $25 \%$. The reliability of clustering patterns in trees was assessed by 1000 bootstrap replicates [33]. Tracer v. 7.0 [34] was used to verify the stabilization moment (ESS values above 200) of the tree samples. The generated tree was visualized and edited in FigTree v.1.4.3 program [35].

\subsection{Experimental Crosses}

Reciprocal experimental crosses were conducted between T. rosai sp. nov. and T. sordida to evaluate the pre- and/or post-zygotic reproductive isolation barriers [36,37]. The experimental crosses were conducted in the Triatominae Insectary of the School of Pharmaceutical Sciences, according to the experiments of Costa et al. [38] and Mendonça et al. [39], the insects were sexed as 5th instar-nymphs, and males and females were kept separately until they reached the adult stage to guarantee the virginity of the insects used in the crosses. For the experimental crosses, three couples from each set were placed in plastic jars (diameter $5 \mathrm{~cm} \times$ height $10 \mathrm{~cm}$ ) and kept at room temperature. Furthermore, intraspecific crosses were also performed for group control. The eggs were collected weekly throughout the female's oviposition periods and the egg fertility rate was calculated. Besides, after the hybrids hatched, the development of 1st instar-nymphs until adults was also monitored weekly to assess the mortality rate. 
Table 1. Species, geographic distribution, and molecular markers used in the phylogenetic studies.

\begin{tabular}{|c|c|c|c|c|c|c|}
\hline \multirow{2}{*}{ Species } & \multirow{2}{*}{ Geographic Distribution } & \multicolumn{5}{|c|}{ Marker } \\
\hline & & COI & Cyt b & $28 \mathrm{~S}$ & $16 S$ & ITS-1 \\
\hline T. sordida & Seabra, Bahia, Brazil & MH029692 & МH054940 & MG417085 & - & * \\
\hline T. sordida & Posses, Goiás, Brazil & MH029695 & * & МH059640 & - & - \\
\hline T. sordida & Monte Azul, Minas Gerais, Brazil & MH029693 & МH054941 & MG417086 & - & - \\
\hline T. sordida & Pantanal, Mato Grosso do Sul, Brazil & MH029694 & KC249292 & KC249210 & KC249075 & - \\
\hline T. sordida & Apolo, La Paz, Bolívia & MH029696 & МH054942 & MH059641 & - & * \\
\hline T. rosai sp. nov. & San Miguel, Corrientes, Argentina & MH029697 & * & MG417088 & - & * \\
\hline T. rosai sp. nov. & San Miguel, Corrientes, Argentina & KC249387 & KC249295 & KC249213 & KC249078 & - \\
\hline T. garciabesi & Rivadavia, Salta, Argentina & MH029698 & МH054943 & MG417089 & - & - \\
\hline T. garciabesi & Rivadavia, Salta, Argentina & KC249338 & КС249249 & КС249158 & KC249006 & - \\
\hline T. guasayana & Santa Cruz, Bolívia & KC249343 & KC249252 & КС249162 & KC249011 & - \\
\hline P. megistus & Nova Prata, Rio Grande do Sul, Brazil & KC249308 & КC249228 & КC249136 & KC248970 & AM949580 \\
\hline
\end{tabular}

* Sequences obtained in this study. 


\subsection{Distribution Map}

Based on Lent and Wygodzynsky [8], Panzera et al. [17,18], Dujardin et al. [40]; Galvão et al. [41], Calderón-Fernández and Juárez [19], and Nattero et al. [20], we prepared a distribution map of T. rosai sp. nov. across Argentina provinces. The map was developed in the QGIS 3.12 program [42], using the layers available at the National Geographic Institute [43] having the World Geodetic System 1984 (WGS 84) Coordinate Reference System as a base.

\section{Results}

\subsection{Systematics}

Family Reduviidae Latreille, 1807

Subfamily Triatominae Jeannel, 1919

Genus Triatoma Laporte, 1832

Triatoma rosai Alevi, Oliveira, Garcia, Cristal, Delgado, Bittinelli, Reis, Ravazi, Oliveira, Galvão, Azeredo-Oliveira, Madeira, 2020 sp. nov. (Figure 1A,B, Figure 2A,B, Figure 3A,C, Figure 4A,C,E, Figure 5A,C,E, Figure 6A,B, Figure 7A-C, Figure 8A,B, Figure 9A-C)
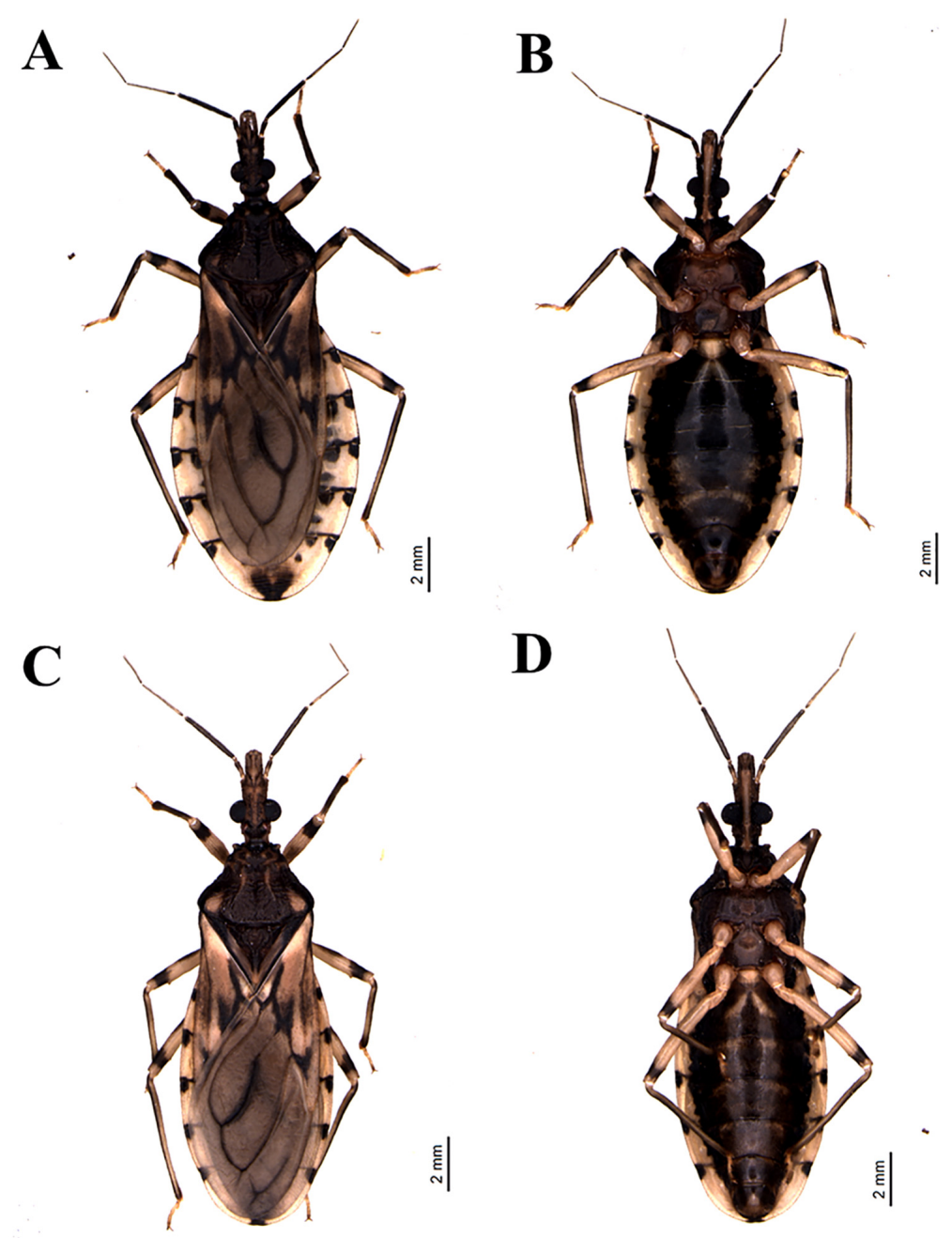

D

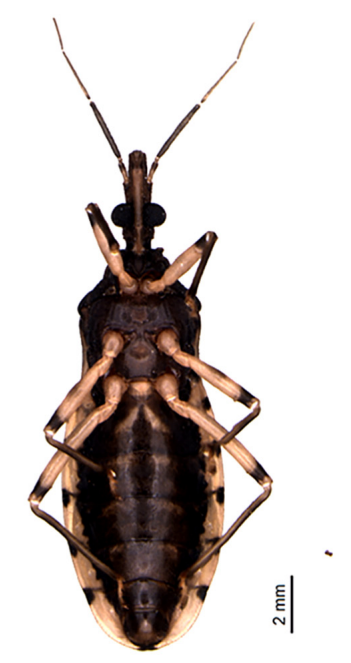

Figure 1. Triatoma rosai sp. nov. male (A) dorsal view, (B) ventral view, Triatoma sordida male (C) dorsal view, (D) ventral view. 

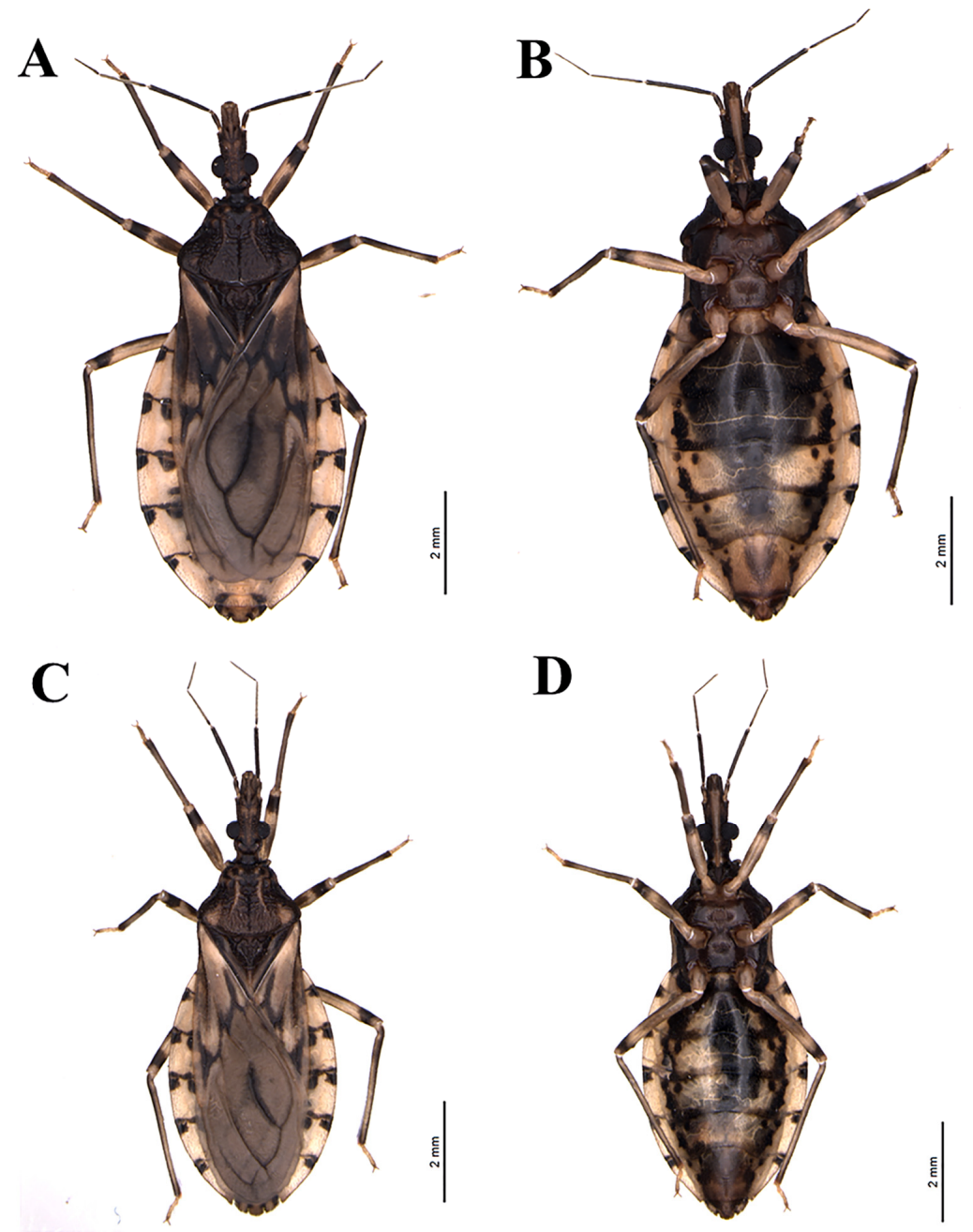

Figure 2. Triatoma rosai sp. nov. female (A) dorsal view, (B) ventral view, T. sordida female (C) dorsal view, (D) ventral view.

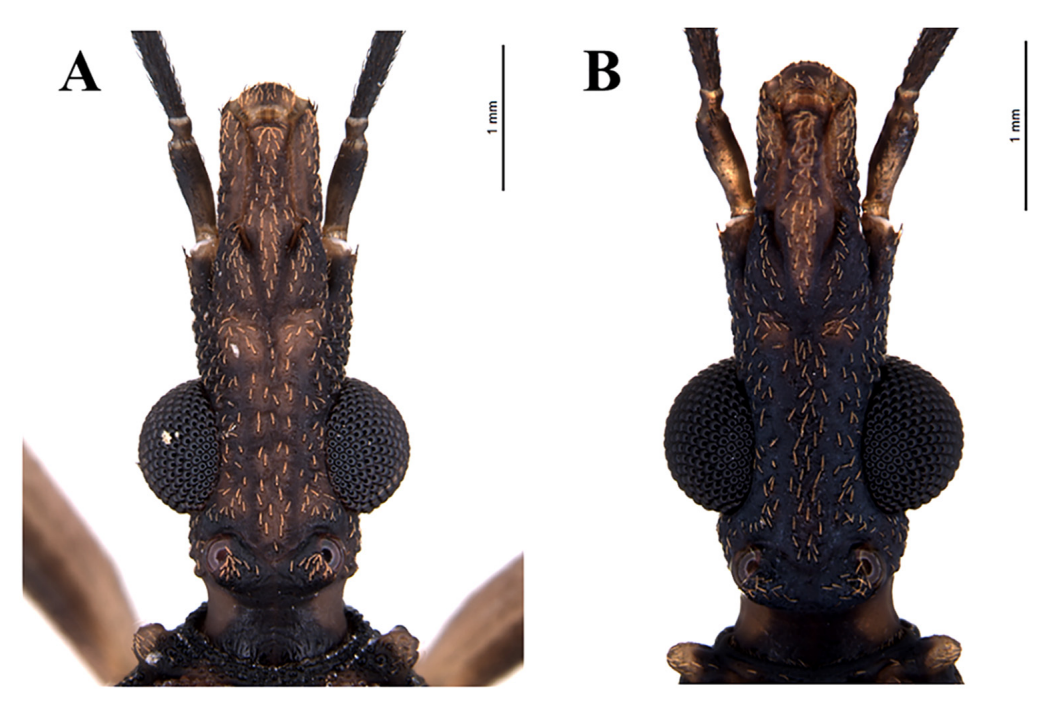

Figure 3. Cont. 
C

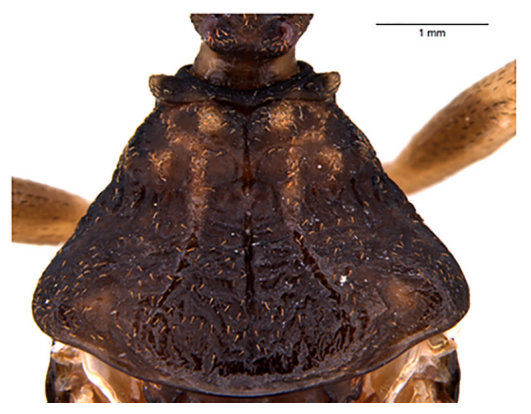

D

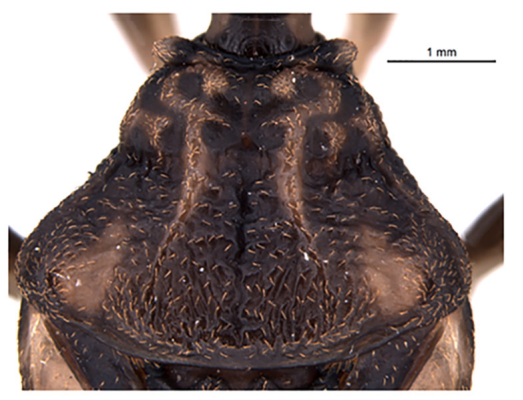

Figure 3. Detail of Head: (A) T. rosai sp. nov. dorsal view, (B) T. sordida dorsal view; detail of Pronotum: (C) T. rosai sp. nov. dorsal view, (D) T. sordida dorsal view.
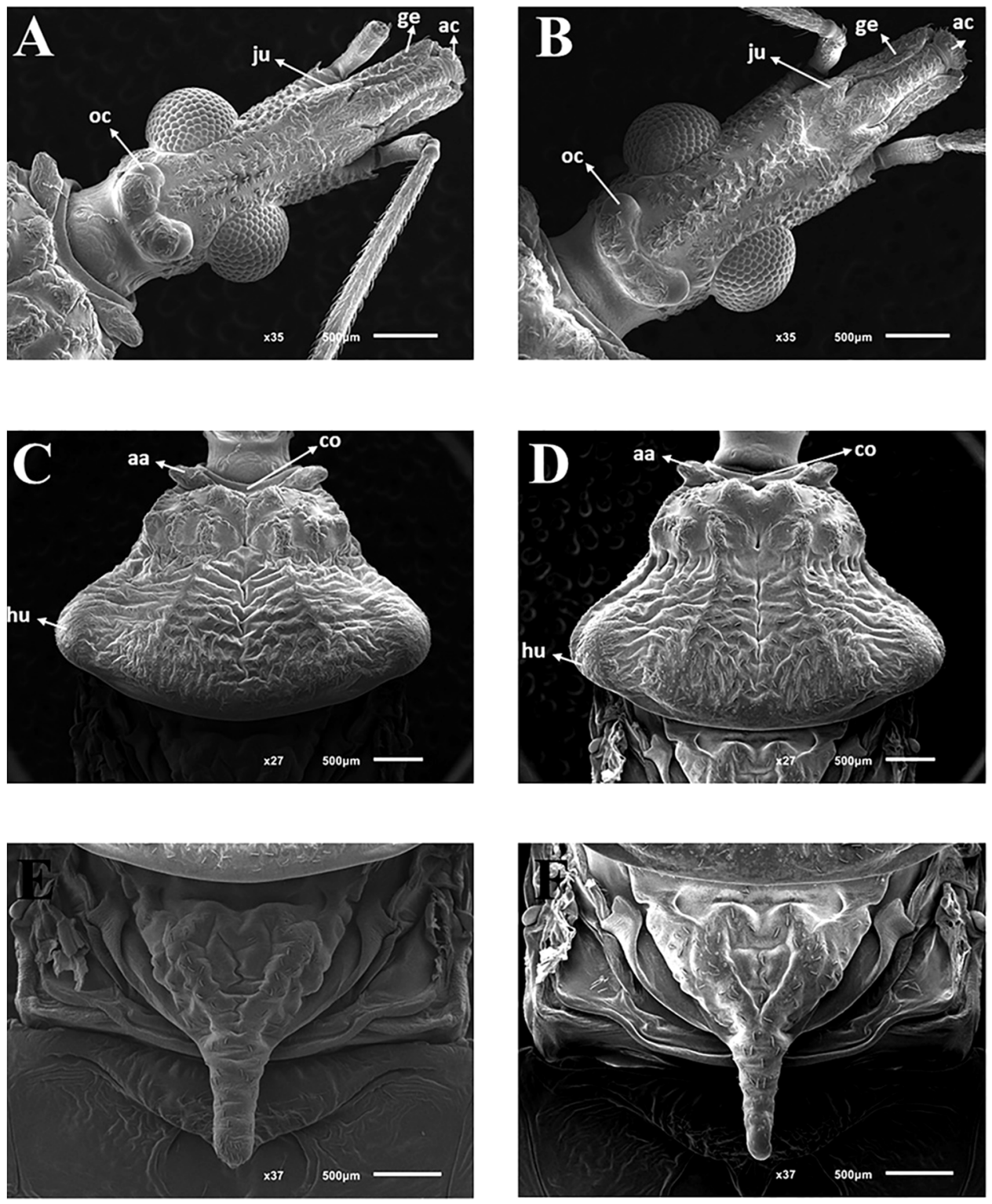

Figure 4. Detail of Head by SEM: (A) T. rosai sp. nov. by dorsal view, (B) T. sordida by dorsal view; Detail of Pronotum by SEM: (C) T. rosai sp. nov. dorsal view (D) T. sordida dorsal view; Detail of scutellum by SEM: (E) T. rosai sp. nov. dorsal view (F) T. sordida dorsal view. ac: anteclypeus; ge: gena; ju: jugum; oc: ocellus; aa: anterolateral angle; co: collar; hu: humeral angles. 

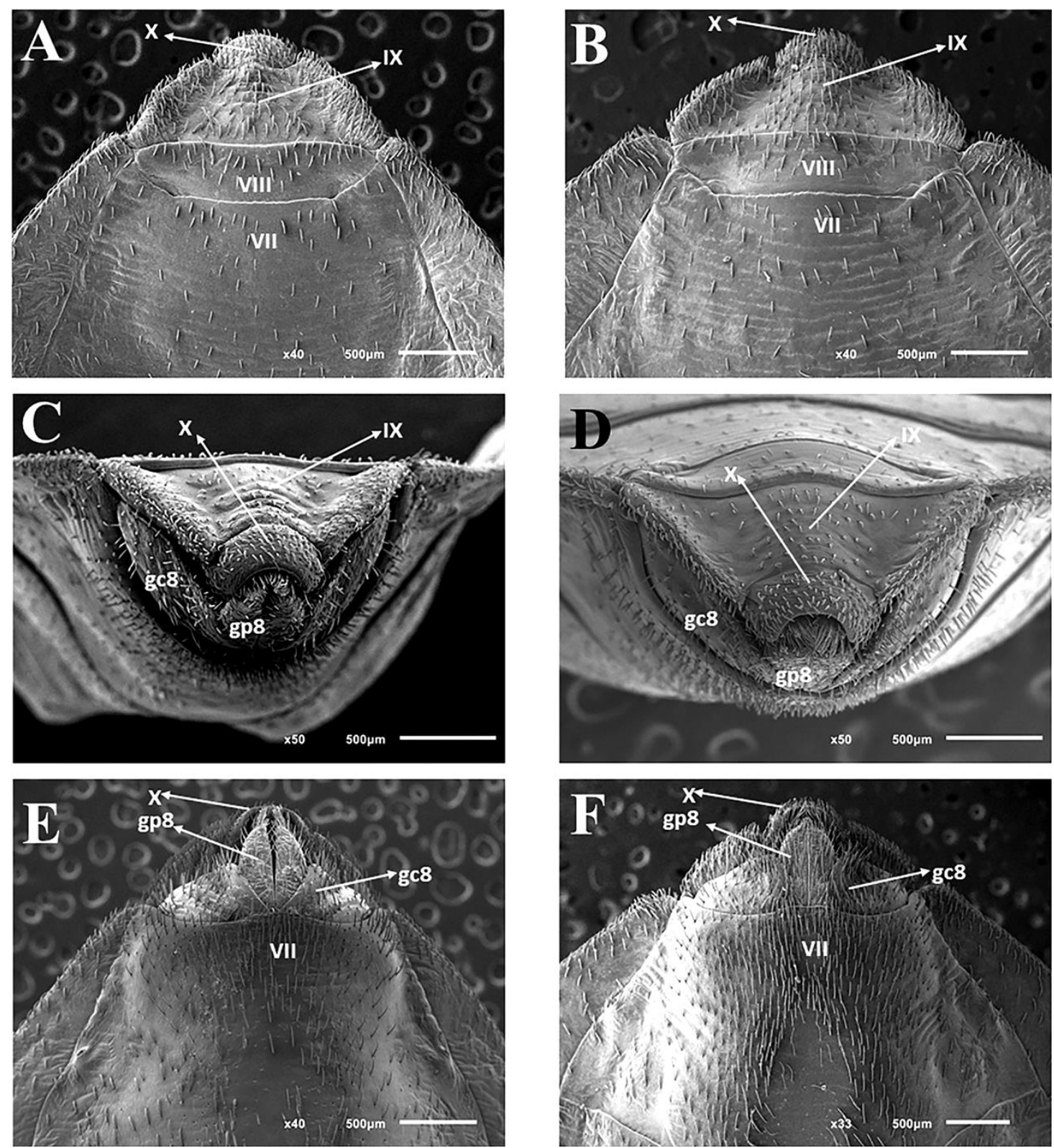

Figure 5. Female external genitalia by SEM: T. rosai sp. nov. (A) dorsal view, (C) posterior view, (E) ventral view, T. sordida: (B) dorsal view, (D) posterior view, (F) ventral view. Gc 8: gonocoxite; Gc 9: gonapophyse; Gp 8: gonapophyse, VII, VIII, IX: tergites; X: segment. 

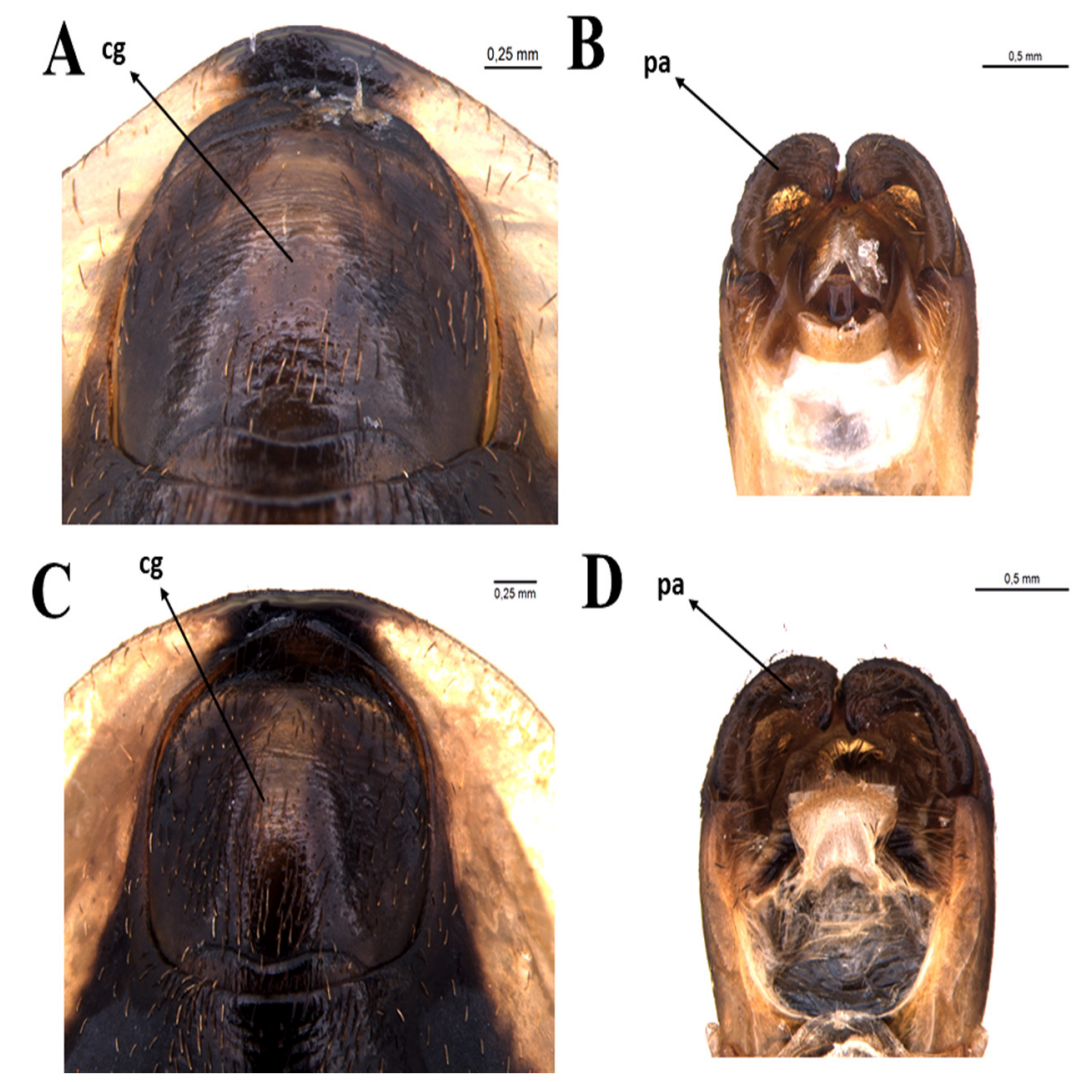

Figure 6. Detail of genital capsule T. rosai sp. nov.: (A) dorsal view, (B) ventral view, T. sordida: (C) dorsal view, (D) ventral view. cg: genital capsule, pa: paramere.

A

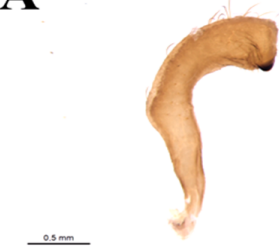

D

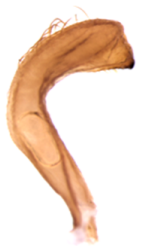

B

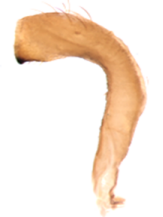

$\mathbf{E}$

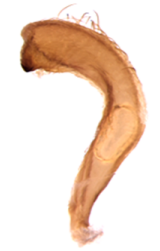

C

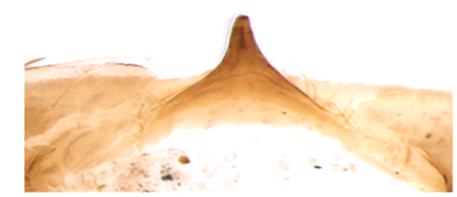

F

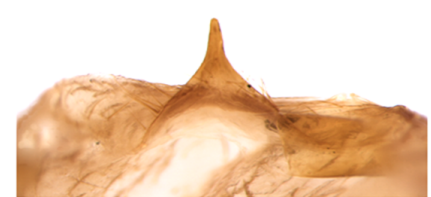

Figure 7. Paramere of T. rosai sp. nov.: (A) dorsal view, (B) ventral view; (C) median process of the pygophore; Paramere of T. sordida: (D) dorsal view, (E) ventral view; (F) median process of the pygophore. 
A

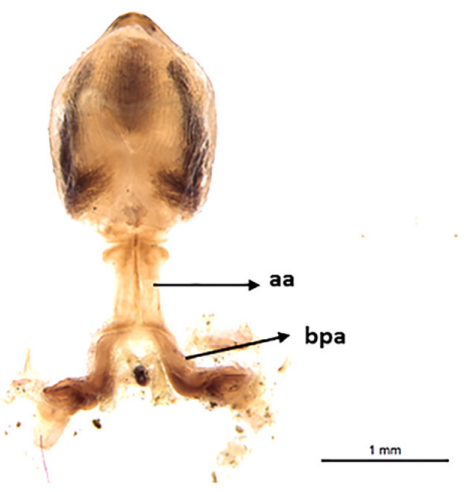

C

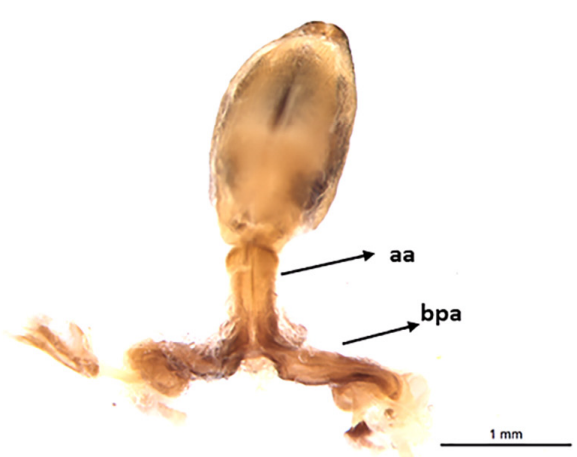

B

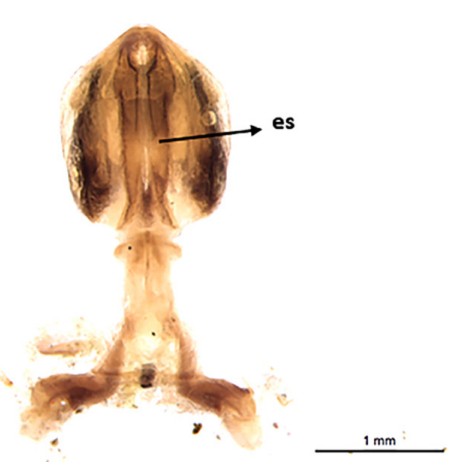

D

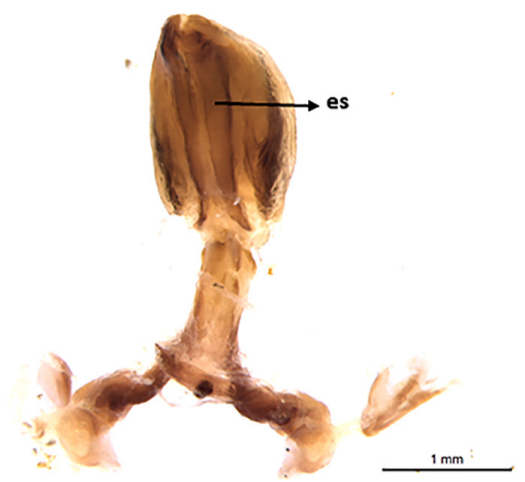

Figure 8. Phallus of T. rosai sp. nov.: (A) dorsal view, (B) ventral view, T. sordida: (C) dorsal view, (D) ventral view. bpa: basal plate arm, aa: articulatory apparatus, es: endosomal struts.

A

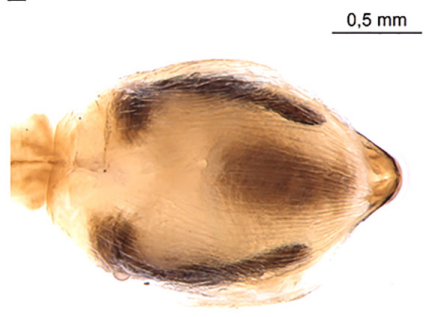

D

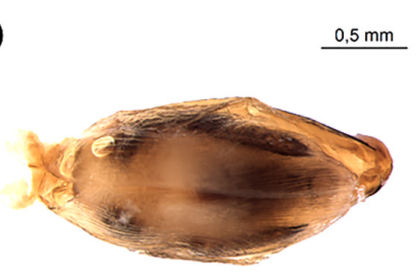

B

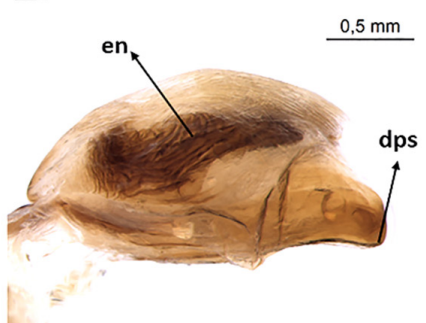

E

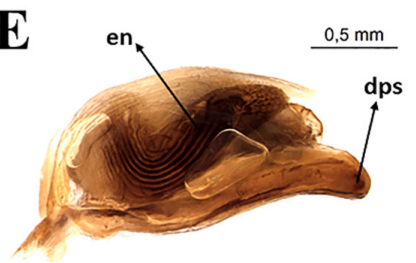

C
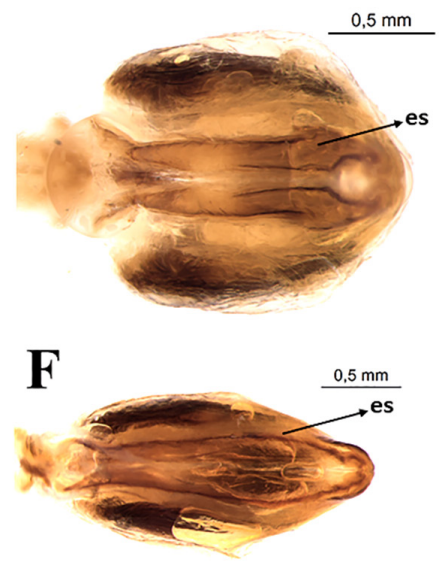

Figure 9. Phallus of T. rosai sp. nov.: (A) dorsal view, (B) lateral view, (C) ventral view; T. sordida: (D) dorsal view, (E) Lateral view, (F) ventral view. en: endosoma, dps: dorsal phallothecal sclerite, es: endosoma struts.

\section{Type Material}

Holotype: male, ARGENTINA, Department San Miguel, Province of Corrientes, 09.08.1999, collection manual, leg. (CEJMSB).

Paratypes: 9 females and 8 males, ARGENTINA, Department San Miguel, Province of Corrientes, 09.08.1999, collection manual, leg. (CEJMSB). 
Additional paratypes. Collection of Triatomines of the Oswaldo Cruz Institute (CTIOC/FIOCRUZ), Rio de Janeiro, Brazil (1 male and 1 female), and Entomological Reference Collection of the Faculty of Public Health (FSP/USP), São Paulo, Brazil (1 male and 1 female).

\subsection{Description}

\subsubsection{Male}

Coloring: general brown color with pale yellowish tones with portions or spots darkened to brownish or blackish (Figure 1A,B and Figure 2A,B). Head, including neck, mainly dark brown with two lateral spots in the catch and darkened or blackened ventrally and laterally behind the eyes; ocellar tubercle, the median portion in the space between the eyes and the apices of dark anteniferous tubercles; first and second antennal segments brown and third and fourth brownish; mostly pale lip, with darkened portions (Figure 3A). Labium with the three visible light brown segments (Figures 1B and 2B). Thorax mainly dark brown in general; pronotum brown (Figure 3C); anterolateral angles blackened with yellowish ends; longitudinal medial groove in the anterior lobe, variable in length, darkened, a spot in pairs in the anterior lobe of yellowish color, posterior lobe of brown coloration; dark brown scutellum on the sides and brownish in the central portion with yellowish apex. Legs generally light brown to yellowish with the following portions or markings darkened: coxae completely yellowed; anterior and medium femurs with an ill-defined complete median or submedian black ring and the apex slightly darkened; these markings can be variable or absent; posterior femur with a distal submedian ring slightly large and incomplete ventrally; tibiae with brownish sub-basal rings, larger in the posterior tibiae and slightly subapically darkened or with the apical third or darkened apical quarter; yellowish tarsi (Figure 1A,B and Figure 2A,B). Hemelytra mostly grayish; with yellowish spots at the base of the dorsal surface, laterally, and in the lateral portion, basally; two black spots at the basal angle of the second disk cell of the membrane; sometimes the basal portions of the veins in that cell are also black. Abdomen, in dorsal view: brownish tergites with some slightly darkened portions, as an intersegmental bridge between the first and second segments, except their lateral portions (Figures 1A and 2A). Connexion with distal areas having two dark spots and whitish pale yellowish basal part, each spot occupying approximately $1 / 4$ of the respective segment; a medium-large oval black spot in the sternite VIII, in ventral view: sternites mostly yellowish; blackened sternites, except in the lateral portions; a pair of wavy black spots on the side, which in some specimens is smaller, incomplete, stained with a pale color in its center, or divided into a pair of sub-median spots, or joined to the sideband by the darkened posterior portion of the segment ( $1 \mathrm{~B}$ and $2 \mathrm{~B}$ ) The markings on the ventral connected segments are generally the same as those on the dorsal portions, but more variable, weakly marked or partially or completely absent in some segments.

Vestiture: when recorded in SEM, it is possible to perceive that the general integument is covered by short, thin, somewhat curved bristles, for example Figures $4 \mathrm{~A}$ and 5A,C,E. Besides, the following vestiture characteristics, also evident under the optical stereomicroscope, were registered: head: smooth eyes; sparse short or slightly longer bristles, clear to yellowish in the distal portion of the clypeus, numerous on the lip; some bristles scattered in the anterior and lateral portions of the base of the first visible lip segment; second visible lip segment with some short, erect bristles inserted on the lateral and subapical surfaces; last lip segment with many upright, long, thin and clear scattered setae.

Clypeus narrow slightly enlarged behind the middle. Genae tapered and slightly apically pointed, distinctly extending beyond the level of the apex of the clypeus. Jugae, apically subangular. Eyes in lateral view reaching the lower level, but not reaching the level of the superior surface of the head. Anteniferous tubercles are inserted behind the middle of the anteocular region. The first antennal segment below the middle of the clypeus level. The first rostral segment is very short, not extending exactly to the level of the apex of the yokes, the second reaching the level of the posterior margin of the eyes (Figure 1A,B, Figure 2A,B, Figure 3A, Figure 4A). 
Anterior lobe of pronotum with discal and lateral tubercles. Submedian carinae extending near the posterior border of the pronotum. Humeral angles are slightly curved, slightly angular. Anterolateral projections of the pronotum small, but detached, narrowly apically rounded. Scutellum has a well-developed central depression. Large scutellar process, about three-quarters of the length of the main body of the scutellum, horizontal, subcylindrical, slightly tapering apically, obliquely truncated distally in the lateral view. Hemelytra approaching or reaching the apex of the seventh urotergite, in males and females I reached half of the seventh urotergite (Figure 1A, Figure 2A, Figure 3C, Figure 4C).

Relatively slender legs, anterior femurs longer than broad. The anterior and middle femurs with subapically robust pair of denticles. Spongy fossulae in the anterior and middle tibias of males, absent in females. Venter convex, weakly flattened in some specimens of both sexes, delicately striated across, sparsely defined. Spiracles variable in position, from adjacent to the connective internal margin to distant from the internal margin by twice its diameter (Figure 1A,B, Figure 2A,B).

Male genitalia: genital capsule rounded, in the ventral view, does not show the exposure of the pigophore (Figure 6A,B) is smooth and shiny integument; in dorsal view (Figure 6A). Sclerotized, triangular (equilateral) pigophore median process (Figure 7C), slightly larger towards the apex; apical margin almost straight, slightly curved (Figure 7C). Parameters (pa) slightly not exposed when the genital capsule is in situ (Figure 6A) or in a ventral view (Figure 6B); their apexes almost touch each other in a resting position (Figure 6B). Symmetrical, elongated, curved approximately in the middle third; slightly larger in the apical quarter; truncated apex, with short subapical tooth on the lower margin; mainly glabrous, with some thin bristles scattered and a group of short, thicker bristles mediated to the subapical tooth (Figure 7A,B), the basal plate arm with moderately short and not curved basal plate arms (bpa), connected by a narrow basal plate bridge (Figure 8A). Endosomal arms formed by a pair of parallel arms, almost straight in the middle portion, larger in the basal portion, joined at the base and at the apex, which are continuous with the dorsal fusion of sclerite-sclerite endosome (Figure 9A). After inflation, the endosome takes on an irregular shape with rough streaks (Figure 9B). The endosome wall striated longitudinally in the basal portion in the ventral view (Figure 9B).

\subsubsection{Female}

Similar to males in general.

\subsection{Female External Genitalia}

Dorsal view of female external genitalia: lines $(1+1)$ limiting the seventh segment with the connexivum are regular (Figure 5A). Posterior portions $(1+1)$ of the seventh segment at the limit with the eighth segment and connecting end in rounded ends (Figure 5A). Connexiva $(1+1)$ of the seventh segment ends in a pointed tip (Figure 5A). The eighth segment shows a trapezoidal shape with rounded edges (Figure 5A). The ninth segment is wavy and the side portions $(1+1)$ form raised flaps (Figure $5 \mathrm{~A})$. The posterior portions $(1+1)$ of the ninth segment have the shape of rounded tips that take the approximate shape of the letter W (Figure 5A).

Posterior view of female external genitalia: the central part of the region that divides the eighth and ninth segments is straight; the junction of the ninth segment IX with the central portion is convex. Being elevated, the lateral portions $(1+1)$ form depressions in the anteroposterior direction (Figure 5B). The boundaries between the ninth and tenth segments are opened on the sides and closed in the central area (Figure 5B). The tenth segment is semicircular (Figure 5B). Gonocoxites 8 are penniform, while gonapophyses 8 are almost triangular (Figure 5B).

Ventral view of female external genitalia: the limit of the seventh segment with gonocoxites 8 and gonapophyses 8 is concave on the sides $(1+1)$ and convex in the central portion (Figure 5C). Posterior portions of the seventh segment connective end in rounded ends (Figure 5C). From this point of view, gonocoxites 8 and gonapophyses $8(1+1)$ are triangular (Figure $5 \mathrm{C}$ ). 


\subsection{Measurement Data}

The measurement data of the studied characters were made available in a table, the characters were: total body length, head length, the internal distance between the eyes, post-ocular head width, pronotum, scutellum, thorax, and abdomen (Table 2).

Table 2. Measurement averages and significance of T. sordida sensu stricto and T. rosai sp. nov. In bold, we present statistically significant measurements.

\begin{tabular}{cccccccccc}
\hline Sex & \multicolumn{1}{c}{ Species } & \multicolumn{8}{c}{ Structures } \\
\hline \multirow{3}{*}{ Male } & & HL & IE & PHW & PRO & SCU & THO & ABD & TL \\
& T. rosai sp. nov. & 5.174 & 0.951 & $\mathbf{1 . 4 9 0}$ & $\mathbf{4 . 7 1 7}$ & $\mathbf{3 . 0 7 7}$ & $\mathbf{6 . 7 0 4}$ & $\mathbf{1 5 . 1 1 7}$ & $\mathbf{2 6 . 9 8}$ \\
& T. sordida & 4.857 & 0.966 & $\mathbf{1 . 3 8 1}$ & $\mathbf{4 . 1 0 7}$ & $\mathbf{2 . 8 1 6}$ & $\mathbf{6 . 0 9 3}$ & $\mathbf{1 4 . 0 8 4}$ & $\mathbf{2 5 . 0 2}$ \\
Female & T. rosai sp. nov. & 5.055 & $\mathbf{1 . 0 0 3}$ & 1.486 & 4.429 & 3.215 & 6.531 & 16.418 & 27.99 \\
& T. sordida & 5.208 & $\mathbf{1 . 0 6 6}$ & 1.510 & 4.221 & 3.214 & 6.459 & 16.167 & 27.81
\end{tabular}

HL: head length; IE: inner distance between eyes; PHW: postocular head width; PRO: pronotum; SCU: scutellum; THO: thorax; ABD: abdomen, TL: total body length; Data in bold: statistically significant measurements.

\subsection{Distribution}

Based on the article by Panzera et al. [17] which indicates that T. sordida sensu stricto and T. sordida La Paz were not notified in Argentina; a distribution map was developed from the notifications of T. rosai sp. nov. (pointed out in the articles as T. sordida from Argentina or T. sordida Argentina [8,17-20,40,41]) in 12 Argentina provinces: Misiones, Corrientes, Santa Fe, Formosa, Chaco, Buenos Aires, Córdoba, Jujuy, Salta, Santiago del Estero, Tucumán and La Rioja (Figure 10).

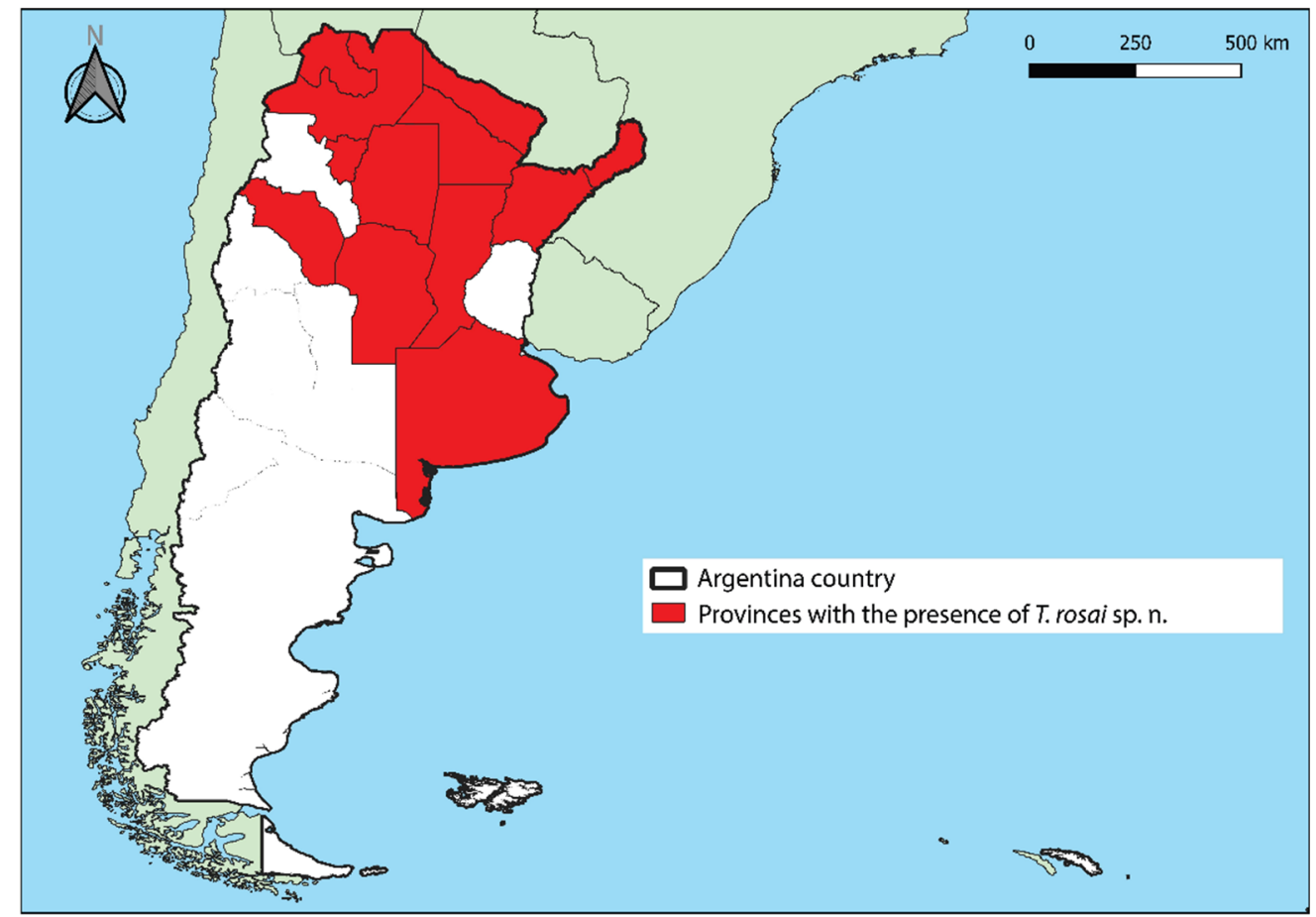

Figure 10. The occurrence of T. rosai sp. nov. in Argentina provinces. Made with QGIS.

\subsection{Observation}

The possible existence of this new species was first noted by Panzera et al. [18] and later mentioned by Dujardin et al. [40], Calderón-Fernández and Juárez [19], Panzera et al. [17] and Nattero et al. [20]. 


\subsection{Etymology}

This species is dedicated to Prof. Dr. João Aristeu da Rosa [Full professor of the School of Pharmaceutical Sciences of São Paulo State University (FCFAR/UNESP), Araraquara, São Paulo, Brazil], one of the world's top authority on triatomine morphology, who has contributed for more than 30 years with taxonomic and systematic studies of these vectors.

\subsection{Phylogenetic Reconstruction and Genetic Distances}

Phylogenetic analyses recovered T. rosai sp. nov. as an independent lineage of $T$. sordida sensu stricto and T. sordida La Paz, as well as T. garciabesi and T. guasayana, and related it as a sister taxon to T. sordida (Figure 11). Pairwise Kimura 2-parameter genetic distances for cyt b gene revealed that T. rosai sp. nov. diverges at least $8.5 \%$ from the lineages of T. sordida sensu stricto (Table 3).

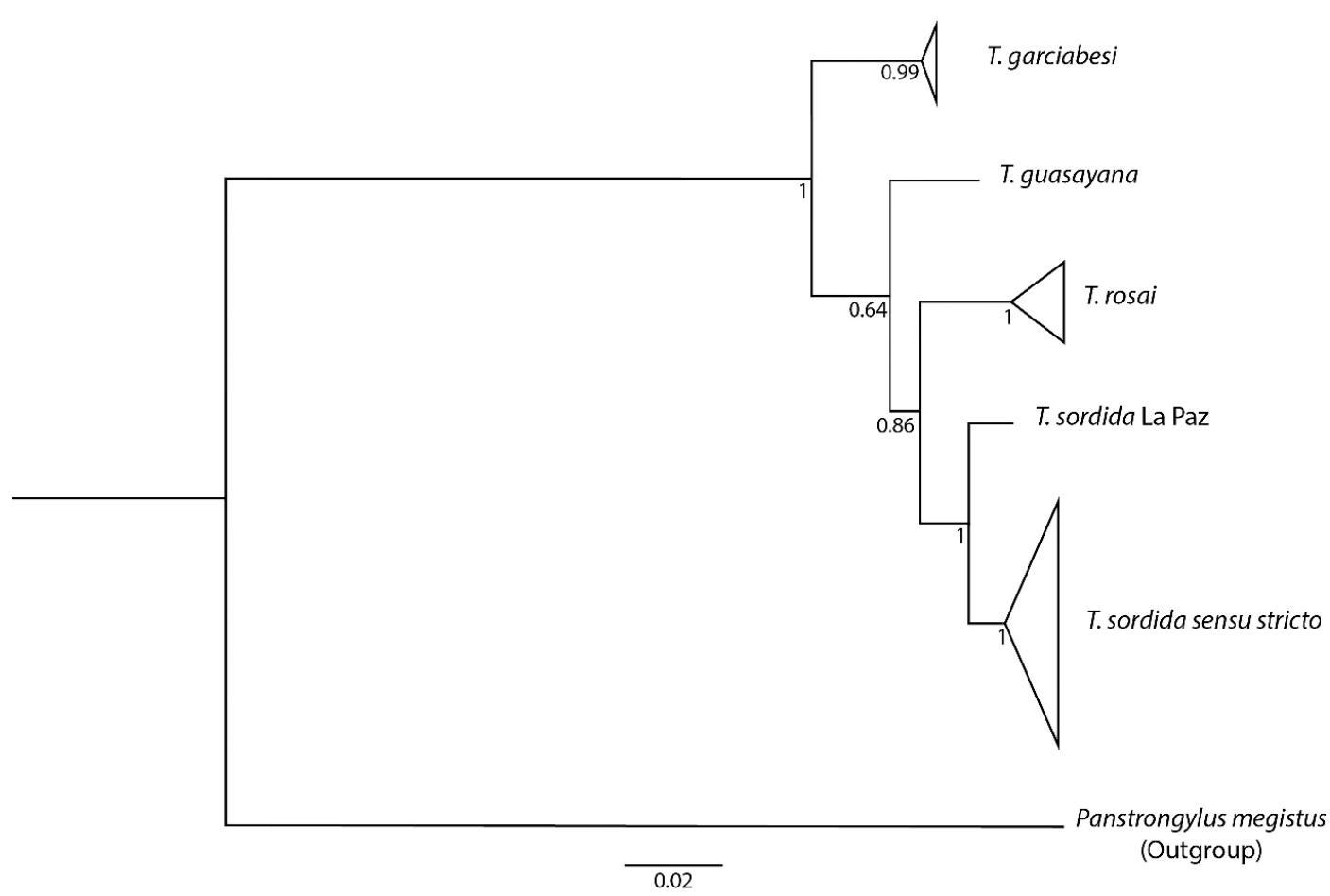

Figure 11. The tree obtained by Bayesian Inference for the concatenated genes COI, cyt $b, 28 S, 16 S$ and ITS-1. The numbers in the nodes represent the bootstrap values.

Table 3. Genetic distance based on cyt b mitochondrial gene. In bold we present the Genetic distance between T. rosai sp. nov. and T. sordida sensu stricto.

\begin{tabular}{lccccccccc}
\hline \multicolumn{1}{c}{ Species } & $\mathbf{( 1 )}$ & $\mathbf{( 2 )}$ & $\mathbf{( 3 )}$ & $\mathbf{( 4 )}$ & $\mathbf{( 5 )}$ & $\mathbf{( 6 )}$ & $\mathbf{( 7 )}$ & (8) & (9) \\
\hline (1) Posse GO * & & & & & & & & & \\
(2) Seabra BA * & 0.007 & & & & & & & & \\
(3) Monte Azul MG * & 0.007 & 0.000 & & & & & & & \\
(4) Pantanal MS * & 0.007 & 0.000 & 0.000 & & & & & & \\
(5) T. rosai sp. nov. & $\mathbf{0 . 0 8 5}$ & $\mathbf{0 . 0 8 7}$ & $\mathbf{0 . 0 8 7}$ & $\mathbf{0 . 0 8 7}$ & & & & & \\
(6) T. garciabesi & 0.082 & 0.074 & 0.074 & 0.074 & 0.099 & & & & \\
(7) T. garciabesi & 0.082 & 0.074 & 0.074 & 0.074 & 0.097 & 0.000 & & & \\
(8) T. guasayana & 0.078 & 0.074 & 0.074 & 0.074 & 0.069 & 0.067 & 0.067 & & \\
(9) P. megistus & 0.245 & 0.234 & 0.234 & 0.234 & 0.259 & 0.240 & 0.241 & 0.244 & \\
\hline
\end{tabular}

* T. sordida sensu stricto; Data in bold: the Genetic distance between T. rosai sp. nov. and T. sordida sensu stricto. 


\subsection{Experimental Crosses}

The crosses between T. rosai sp. nov. and T. sordida sensu stricto resulted in hybrids (absence of pre-zygotic barrier) (Table 4). However, hybrids showed a high mortality rate when compared to parental crosses (post-zygotic barrier by hybrid inviability) (Table 4).

Table 4. Experimental crosses performed between T. sordida sensu stricto and T. rosai sp. nov.

\begin{tabular}{|c|c|c|c|c|}
\hline Experimental Crosses & $\begin{array}{c}\text { Number of } \\
\text { Eggs }\end{array}$ & $\begin{array}{c}\text { Hatching } \\
\text { Rate }\end{array}$ & $\begin{array}{c}\text { Number of } \\
\text { Nymphs }\end{array}$ & $\begin{array}{c}\text { Mortality } \\
\text { Rate }\end{array}$ \\
\hline \multicolumn{5}{|l|}{ Interspecific } \\
\hline o T. sordida sensu stricto $\times$ T. rosai sp. nov. $\sigma^{T}$ & 241 & $77 \%$ & 186 & $80 \%$ \\
\hline T. rosai sp. nov. x T. sordida sensu stricto $0^{7}$ & 237 & $59 \%$ & 139 & $73 \%$ \\
\hline \multicolumn{5}{|l|}{ Intraspecific } \\
\hline o T. sordida sensu stricto $\times$ T. sordida sensu stricto $0^{T}$ & 590 & $73 \%$ & 429 & $20 \%$ \\
\hline T. rosai sp. nov. $\times$ T. rosai sp. nov. $\sigma^{7}$ & 208 & $61 \%$ & 125 & $17 \%$ \\
\hline
\end{tabular}

\subsection{Taxonomic Notes}

Triatoma sordida (Stål, 1859) (Figure 1C,D, Figure 2C,D, Figure 3B,D, Figure 4B,D,F, Figure 5B,D,F, Figure 6C,D, Figure 7D-F, Figure 8C,D, Figure 9D-F, Figure 12A,B).

Conorhinus sordidus Stål, 1859,

Triatoma sordida Chagas, 1912

Eutriatoma sordida Pinto, 1931

Triatoma sordida Lent and Wygodzinsky 1979

\subsubsection{List of Synonymous}

List of Synonymous: Conorhinus sordidus Stål, 1859 and Eutriatoma Sordida Pinto, 1931 [11].

\subsubsection{Distribution}

Distribution: Brazil: Acre, Bahia, Goiás, Maranhão, Mato Grosso, Mato Grosso do Sul, Minas Gerais, Paraná, Pernambuco, Piauí, Rio Grande do Sul, Santa Catarina, São Paulo and Tocantins. Distribution outside Brazil: Bolívia, Paraguay and Uruguay [11,44].

\subsubsection{Type Material}

Type material: deposited at the Zoologisches Museum, Berlin, Germany [45] (Figure 12).

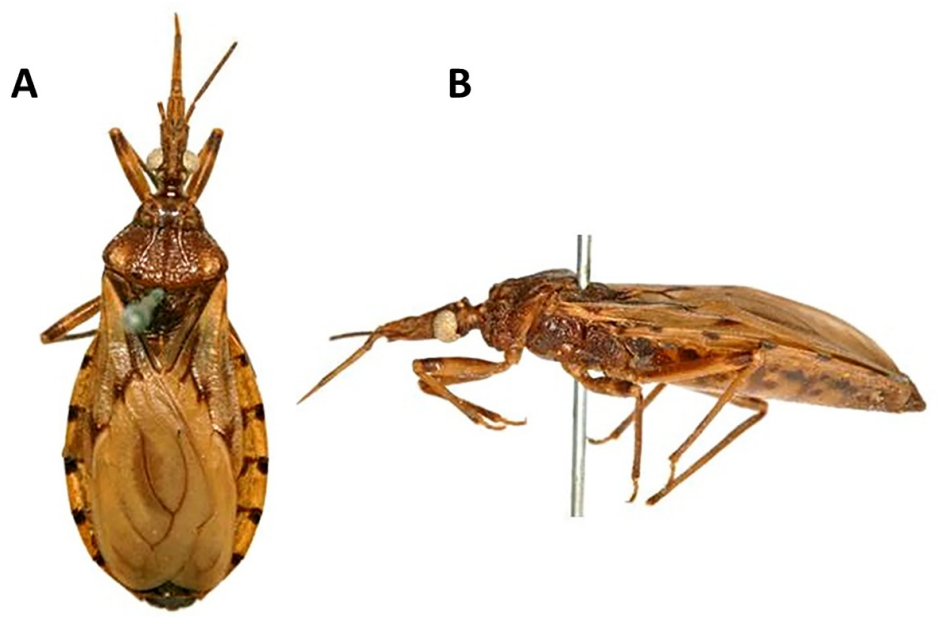

Figure 12. Holotype of T. sordida described by Stål in 1859 (as Conorhinus sordidus) and deposited in the Zoologisches Museum, Berlim, Alemanha, A-Dorsal view; B-Lateral view. 


\subsubsection{Comments}

Comments: all aspects used in this description of T. rosai sp. nov. were compared with the type specimen and with a population from the same state.

\subsection{Literature Data}

\subsubsection{Genetics Differences}

\section{Cytogenetics Differences}

The cytogenetic characterization of T. rosai sp. nov. was carried out by Panzera et al. $[17,18]$ and Bardella et al. [46] (termed as T. sordida Argentina) and demonstrated great differences when compared to T. sordida sensu stricto: T. rosai sp. nov. [absence of heterochromatin and $\mathrm{CMA}_{3} / \mathrm{DAPI}$ bands in autosomes, chromocenter formed only by sex chromosomes, $\mathrm{Y}$ sex chromosome is $\mathrm{DAPI}^{+}$ with $\mathrm{CMA}_{3}{ }^{+}$dots, and $45 \mathrm{~S}$ rDNA clusters were observed in both sex chromosomes ( $\mathrm{X}$ and $\left.\mathrm{Y}\right)$ ] and T. sordida sensu stricto [presence of heterochromatic blocks on a chromosomal end (8 to 10 autosomes), all bivalents showed $\mathrm{CMA}^{+} / \mathrm{DAPI}^{+}$regions co-localized, chromocenter formed by sex chromosomes and autosomes, $\mathrm{Y}$ sex chromosome $\mathrm{DAPI}^{+}$and negative for $\mathrm{CMA}_{3}$, and $45 \mathrm{~S}$ rDNA clusters were observed in $\mathrm{X}$ sex chromosome].

\section{Electrophoresis Pattern}

The electrophoretic profile of T. rosai sp. nov. (termed as T. sordida Argentina) was characterized by Panzera et al. [18]. The authors noted that of the 14 enzyme systems studied, three diagnostic loci evaluated among T. rosai sp. nov. and T. sordida sensu stricto showed no common alleles [GPI (11), PEP-1 (11), PEP-2 (11), and GPI (33), PEP-1 (22), PEP-2 (22), respectively].

\section{Molecular Analyses}

Garcia et al. [47], using mtDNA fragments of $12 \mathrm{~S}$ and $16 \mathrm{~S}$ ribosomal RNA genes observed, for the first time, phylogenetic divergences between T. sordida from Brazil and T. rosai sp. nov. (termed as T. sordida from Argentina) since the specimens from Argentina were closer to T. matogrossensis Leite and Barbosa, 1953 than to T. sordida from Brazil. Posteriorly, the phylogenetic analyses performed by Panzera et al. [17] with the mitochondrial gene COI demonstrated that T. rosai sp. nov. (termed as T. sordida Argentina) constituted a monophyletic clade with $88 \%$ bootstrap. The authors also observed a genetic distance between T. rosai sp. nov. and T. sordida sensu stricto of $5.3 \%$. Belintani et al. [48] performed a phylogenetic study combining COI, cyt b, 16S, 18S and 28S genes and observed that T. sordida populations were separated into two well-defined strains: T. sordida (Bolivia and Brazil) and T. rosai sp. nov. (termed as T. sordida Argentina). This division is corroborated by phylogenetic reconstruction, species delimitations based on Poisson Tree Process (PTP), and values of genetic distances. Finally, Madeira et al. [49], through phylogenetic analyzes with cyt $b$ and ND1 genes, clearly demonstrated the difference between T. rosai sp. nov. (termed as T. sordida from Argentina) and T. sordida sensu stricto from different locations in Brazil (Bahia: Gentio de Ouro, Macaúbas, Seabra, and Tanhaçu; Goiás: Posse; Minas Gerais: Brasília de Minas, Catuti, Monte Azul, Porteirinha, and Riacho dos Machados; Mato Grosso do Sul: Corumbá and Pantanal).

\subsubsection{Morphological Differences}

\section{Cuticular Hydrocarbons Pattern}

The cuticular hydrocarbons analyses of T. rosai sp. nov. (termed as T. sordida of Argentina) and T. sordida sensu stricto performed by Calderón-Fernández and Juárez [19] comprised that both species showed significantly different hydrocarbon profiles. 


\section{Geometric Morphometry}

Morphometric analyses of the head, wings, and thorax performed in T. rosai sp. nov. (termed as T. sordida Argentina) and T. sordida sensu stricto by Nattero et al. [20] demonstrated divergences between all measured characters. Neighbor-joining trees derived from Mahalanobis distances from head and wing measurements clearly differentiated T. rosai sp. nov. and T. sordida sensu stricto [20].

\subsubsection{Life Cycle and Average Time of Development}

According to Oscherov et al. [50], T. rosai sp. nov. (termed as T. sordida from Argentina) has an average development time of all nymph stages of approximately 303 days, while T. sordida sensu stricto has an average time of nymph development of approximately 170 days [51]. Oscherov et al. [50] also reported that the life cycle of T. rosai sp. nov. is completed in about 10 months, unlike T. sordida sensu stricto that completes its cycle in just five months [52].

\section{Geographic Distribution}

According to Panzera et al. [17], T. rosai sp. nov. (termed as T. sordida Argentina) is present in Argentina, Bolivia, and Paraguay, and T. sordida sensu stricto is present in Brazil, Bolivia, and Paraguay. Although species may overlap in Bolivia and Paraguay, there are no reports of T. rosai sp. nov. in Brazil, as well as T. sordida sensu stricto in Argentina (the papers already published with T. sordida coming from Argentina were performed with T. rosai sp. nov. [9,17-20,40,41,46-50,53-75])

\section{Discussion}

Triatoma rosai sp. nov., in conjunction with T garciabesi, T. jurbergi Carcavallo, Galvão, and Lent, 1998, T. matogrossensis, T. sordida, and T. vandae Carcavallo, Jurberg, Rocha, Galvão, Noireau, and Lent, 2002 constitute the monophyletic T. sordida subcomplex [48,76]. Several authors, based mainly on morphological data and geographic distribution, considered T. sordida subcomplex as a group formed by four species (T. garciabesi, T. guasayana; T. patagonica Del Ponte, 1929, and T. sordida) [40,77,78]. Genetic studies (cytogenetics and phylogenetics) have shown that, in fact, T. guasayana and T. patagonica have an evolutionary relationship with the T. rubrovaria subcomplex $[48,76]$.

In addition to T. rosai sp. nov., there are 16 species reported in Argentina: P. coreodes Bergroth, 1911, P. geniculatus (Latreille, 1811), P. guentheri Berg, 1879, P. megistus, P. rufotuberculatus (Champion, 1899), T. breyeri Del Ponte, 1929, T. delpontei Romaña and Abalos, 1947, T. eratyrusiformis Del Ponte, 1929, T. garciabesi, T. guasayana, T. infestans (Klug, 1834), T. limai Del Ponte, 1929, T. patagonica, T. platensis Neiva, 1913, T. rubrofasciata (De Geer, 1773) and T. rubrovaria (Blanchard, 1843) [41]. Taking into account that $T$. garciabesi shows great morphological similarity with T. sordida (which even led to a synonymization event) $[8,9,17]$, the difficulty of morphological differentiation of T. guasayana and T. sordida (especially in the nymphal stages) and the fact that the geographic distribution of both species overlaps in northern Argentina [17], we included these taxa in our phylogenetic studies and confirmed that T. rosai sp. nov. is a distinct species.

Several phylogenetic studies showed that T. rosai sp. nov. (termed as T. sordida Argentina) differs from T. sordida (T. sordida sensu stricto and T. sordida La Paz) [17,47-49]. Our results based on integrative taxonomy confirmed that the initial divergences reported as "intraspecific variation" [17-20] represent interspecific differences, being T. rosai sp. nov. an independent strain of T. sordida. The last two species of Triatoma described (T. mopan Dorn et al., 2018 and T. huehuetenanguensis Lima-Cordón et al., 2019) were also based on integrative taxonomy, which provides greater reliability of the specific status of these new taxa $[79,80]$.

Among the different tools that can support the integrative taxonomy, the performance of experimental crossings and the analyses of pre- and post-zygotic interspecific reproductive barriers are of great importance to assess the specific status of taxa (based on the biological concept of species) [36,37]. The characterization of pre-zygotic barriers that prevent the formation of hybrids is important from 
a taxonomic point of view since they demonstrate that the species are genetically isolated (with no interspecific gene flow) [36]. However, the high mortality rate observed among hybrids resulting from crosses between T. rosai sp. nov. and T. sordida sensu stricto demonstrates in turn that, in addition to the physical barriers that possibly prevent the meeting of these insects in nature (because they live in different countries in South America [17]), there are evolutionary events that lead to a low adaptive value of hybrids. There are several examples of triatomine species that do not have pre-zygotic reproductive barriers, but that had the specific status supported by the post-zygotic barriers (inviability, sterility, or hybrid breakdown) that make hybrids unfeasible [39,81-88].

Triatoma rosai sp. nov. (referred in the article as T. sordida Argentina) is a wild species, k strategist, present between dry and fallen trunks, tree holes, bromeliads, palm trees, in opossum (Didelphis spp.) houses and in dry cacti, which was found naturally infected with T. cruzi and is considered responsible for the parasite's wild cycle (mainly associated with bird nests). This species has also been reported in rural peridomestic (such as goat corrals), as well as in domiciliary areas (houses, in general, which were 300 to $2700 \mathrm{~m}$ away from pigeon nests) $[54,57,59,63,64,67,69,70]$.

A survey carried out on palm trees in the province of Corrientes, Argentina showed that T. rosai sp. nov. (termed as T. sordida Argentina) has a high rate of infection with T. cruzi, since $38.5 \%$ of the specimens analyzed were infected - it is believed that prawns and rodents are the reservoirs of the parasite in palm trees [59]. Maffey et al. [72] also suggest that T. rosai sp. nov. probably is the vector of T. cruzi genotype I (TcI) among opossums and can act as a secondary vector of the TcVI and TcV genotypes in domestic and peridomestic cycles. These data are of great epidemiological importance since the infection rate of T. rosai sp. nov. is extremely high when compared to T. sordida sensu stricto (rates ranging from $0.5 \%$ to $16.2 \%$ [89-92]) and highlights the importance of epidemiological surveillance of this species in Argentina, where has about two to three million people infected (of which approximately 800,000 are chronic heart patients), being 20 million inhabitants living at risk and, above all, nine out of ten new Chagas' disease cases occurring in children in the country [93].

\section{Conclusions}

Based on the above, we describe T. rosai sp. nov., highlight the importance of integrative taxonomy for the description of new species of triatomines, and, above all, demonstrate the need for the attention of vector control programs in Argentina for this new species of Chagas disease vector.

Author Contributions: Conceptualization, K.C.C.A., J.d.O., C.G., F.F.M., and M.T.V.d.A.-O.; methodology, K.C.C.A., J.d.O., A.C.C.G., D.C.C., L.M.G.D., I.d.F.B., Y.V.d.R., A.R., A.B.B.d.O., and F.F.M.; formal analysis, K.C.C.A., J.d.O., A.C.C.G., D.C.C., L.M.G.D., I.d.F.B., Y.V.d.R., A.R., A.B.B.d.O., and F.F.M.; investigation, K.C.C.A., J.d.O., A.C.C.G., D.C.C., L.M.G.D., I.d.F.B., Y.V.d.R., A.R., A.B.B.d.O., F.F.M., C.G., and M.T.V.d.A.-O.; resources, K.C.C.A., J.d.O., C.G., and M.T.V.d.A.-O.; writing-original draft preparation, K.C.C.A., A.C.C.G., J.d.O., and F.F.M.; writing-review and editing, K.C.C.A., J.d.O., A.C.C.G., D.C.C., L.M.G.D., I.d.F.B., Y.V.d.R., A.R., A.B.B.d.O., F.F.M., C.G., and M.T.V.d.A.-O.; supervision, K.C.C.A. and M.T.V.d.A.-O.; project administration, K.C.C.A. and M.T.V.d.A.-O.; funding acquisition, K.C.C.A., C.G., and M.T.V.d.A.-O. All authors have read and agreed to the published version of the manuscript.

Funding: This research was funded by Fundação de Amparo à Pesquisa do Estado de São Paulo (FAPESP) (Process number 2017/05015-7, 2018/12039-2, 2018/24116-1 and 2020/07917-0), Conselho Nacional de Desenvolvimento Científico e Tecnológico (CNPq) and by the Coordenação de Aperfeiçoamento de Pessoal de Nível Superior-Brazil (CAPES)-Finance Code 001.

Acknowledgments: We are very grateful to Jürgen Deckert (Museum für Naturkunde, Berlin, Germany) for the photos and information provided about the T. sordida holotype deposited in your institution. Besides that, we also thank Genivaldo de Oliveira Navarro and Milton Cesar for all the field support in Riacho dos Machados, Minas Gerais, Brazil.

Conflicts of Interest: The authors declare no conflict of interest.

\section{References}

1. Rodriguez, J.B.; Falcone, B.N.; Szajnman, S.H. Detection and treatment of Trypanosoma cruzi : A patent review (2011-2015). Expert. Opin. Ther. Pat. 2016, 26, 993-1015. [CrossRef] [PubMed] 
2. Pérez-Molina, J.A.; Molina, I. Chagas disease. Lancet 2018, 391, 82-94. [CrossRef]

3. World Health Organization. Available online: https://www.who.int/news-room/fact-sheets/detail/chagasdisease-(american-trypanosomiasis) (accessed on 18 September 2020).

4. Pan American Health Organization. Available online: https://www.paho.org/hq/index.php?option=com content\&view $=$ article\&id $=13566 \&$ Itemid $=40721 \&$ lang $=$ pt (accessed on 18 September 2020).

5. Dias, J.C.P.; Ramos, A.N., Jr.; Gontijo, E.D.; Luquetti, A.; Shikanai-Yasuda, M.A.; Coura, J.R.; Torres, R.M.; Melo, J.R.C.; Almeida, E.A.; Oliveira, W., Jr.; et al. 2nd Brazilian consensus on Chagas disease. Rev. Soc. Bras. Med. Trop. 2016, 49, 3-60. [CrossRef] [PubMed]

6. Galvão, C. Taxonomia dos Vetores da Doença de Chagas da Forma à Molécula, quase três séculos de história. In Atualidades em Medicina Tropical no Brazil: Vetores; Oliveira, J., Alevi, K.C.C., Camargo, L.M.A., Meneguetti, D.U.O., Eds.; Stricto Sensu: Rio Branco, Brazil, 2020; pp. 9-37. [CrossRef]

7. Chagas, C. Nova tripanozomiaze humana: Estudos sobre a morfolojia e o ciclo evolutivo do Schizotrypanum cruzi n. gen., n. sp., ajente etiolojico de nova entidade morbida do homem. Mem. Inst. Oswaldo Cruz 1909, 1, 159-218. [CrossRef]

8. Lent, H.; Wygodzynsky, P. Revision of the Triatominae (Hemiptera-Reduviidae) and their significance as vectors of Chagas' disease. Bull. Am. Mus. Nat. Hist. 1979, 163, 123-520. Available online: http: //hdl.handle.net/2246/1282 (accessed on 18 September 2020).

9. Gurgel-Gonçalves, R.; Ferreira, J.B.C.; Rosa, A.F.; Bar, M.E.; Galvão, C. Geometric morphometrics and ecological niche modelling for delimitation of near-sibling triatomine species. Med. Vet. Entomol. 2011, 25, 84-93. [CrossRef]

10. Gurgel-Gonçalves, R.; Galvão, C.; Costa, J.; Peterson, A.T. Geographic distribution of Chagas disease vectors in Brazil based on ecological niche modeling. J. Trop. Med. 2012, 2012, 1-15. [CrossRef]

11. Galvão, C. Vetores da doença de Chagas no Brazil; Sociedade Brazileira de Zoologia: Curitiba, Brazil, 2014; p. 165. [CrossRef]

12. Abalos, J.W.; Wygodzinsky, P. Las Triatominae Argentinas (Reduviidae, Hemiptera). Publ. Inst. Med. Reg. Univ. Nac. 1951, 601,1-179. Available online: https://peerj.com/preprints/3006v1/Article_S1.pdf (accessed on 18 September 2020).

13. Actis, A.S.; Traversa, O.C.; Carcavalho, R.U. Estudios taxonómicos sobre el genero Triatoma Laporte mediante la electrophoresis de la linfa. An. Esc. Nac. Cienc. Biol. 1964, 3, 97-106.

14. Carcavallo, R.U.; Cichero, J.A.; Martínez, A.; Prosen, A.F.; Ronderos, R. Una nueva espécie del género Triatoma Laporte (Hemiptera, Reduviidae, Triatominae). Segundas Jorn. Entomo-Epidemiológicas Argent. 1967, 2, $43-48$.

15. Jurberg, J.; Galvão, C.; Lent, H.; Monteiro, F.; Lopes, M.C.; Panzera, F.; Pérez, R. Revalidação de Triatoma garciabesi Carcavallo, Cichero, Martínez, Prozen \& Ronderos, 1967 (Hemiptera, Reduviidae). Entomol. Vectores 1998, 5, 107-122. Available online: http://refhub.elsevier.com/S0001-706X(20)30147-9/sbref0029 (accessed on 18 September 2020).

16. Noireau, F.; Gutierrez, T.; Zegarra, M.; Flores, R.; Brenière, F.; Cardozo, L. Cryptic speciation in Triatoma sordida (Hemiptera: Reduviidae) from the Bolivian Chaco. Trop. Med. Int. Health 1998, 3, 364-372. [CrossRef] [PubMed]

17. Panzera, F.; Pita, S.; Nattero, J.; Panzera, Y.; Galvão, C.; Chavez, T. Cryptic speciation in the Triatoma sordida subcomplex (Hemiptera, Reduviidae) revealed by chromosomal markers. Parasit. Vectors 2015, 8, 495-504. [CrossRef]

18. Panzera, F.; Hornos, S.; Pereira, J.; Cestau, R.; Canale, D.; Diotaiuti, L.; Dujardin, J.P.; Perez, R. Genetic variability and geographic differentiation among three species of triatomine bugs (Hemiptera-Reduviidae). Am. J. Trop. Med. Hyg. 1997, 57, 732-739. [CrossRef] [PubMed]

19. Calderón-Fernández, G.M.; Juárez, M.P. The cuticular hydrocarbons of the Triatoma sordida species subcomplex (Hemiptera: Reduviidae). Mem. Inst. Oswaldo Cruz 2013, 108, 778-784. [CrossRef]

20. Nattero, J.; Piccinali, R.M.; Lopes, C.M.; Hernandez, M.L.; Abrahan, L.; Lobbia, P.A.; Rodríguez, C.S.; Carbajal-de-la-Fuente, N.A. Morphometric variability among the species of the Sordida subcomplex (Hemiptera: Reduviidae: Triatominae): Evidence for differentiation across the distribution range of Triatoma Sordida. Parasit. Vectors 2017, 10, 412. [CrossRef]

21. Rosa, J.A.; Rocha, C.S.; Gardim, S.; Pinto, M.C.; Mendonça, V.J.; Ferreira-Filho, J.C.R.; Carvalho, E.O.C.; Camargo, L.M.A.; Oliveira, J.; Nascimento, J.D.; et al. Description of Rhodnius montenegrensis n. sp. (Hemiptera, Reduviidae: Triatominae) from the state of Rondônia, Brazil. Zootaxa 2012, 3478, 62-76. [CrossRef] 
22. Monteiro, F.A.; Perez, R.; Panzera, F.; Dujardin, J.P.; Galvão, C.; Rocha, D.; Noireau, F.; Schofield, C.J.; Beard, C.B. Mitochondrial DNA variation of Triatoma infestans populations and its implication on the specific status of T. melanosoma. Mem. Inst. Oswaldo Cruz 1999, 94, 229-238. [CrossRef]

23. Tartarotti, E.; Ceron, C.R. Ribosomal DNA ITS-1 intergenic spacer polymorphism in triatomines (Triatominae, Heteroptera). Biochem. Genet. 2005, 43, 365-373. [CrossRef]

24. Hall, T.A. BioEdit: A user-friendly biological sequence alignment editor and analysis program for Windows 95/98/NT. Nucleic Acids Symp. Ser. 1999, 41, 95-98. [CrossRef]

25. Thompson, J.; Higgins, D.; Gibson, T. CLUSTAL W: Improving the sensitivity of progressive multiple sequence alignment through sequence weighting, position specific gap penalties and weight matrix choice. Nucleic Acids Res. 1994, 22, 4673-4680. [CrossRef] [PubMed]

26. Tamura, K.; Stecher, G.; Peterson, D.; Filipski, A.; Kumar, S. MEGA6: Molecular Evolutionary Genetics Analysis version 6.0. Mol. Biol. Evol. 2013, 30, 2725-2729. [CrossRef] [PubMed]

27. Kumar, S.; Stecher, G.; Li, M.; Knyaz, C.; Tamura, K. MEGA X: Molecular Evolutionary Genetics Analysis across computing platforms. Mol. Biol. Evol. 2018, 35, 1547-1549. [CrossRef] [PubMed]

28. Edgar, R.C. MUSCLE: Multiple sequence alignment with high accuracy and high throughput. Nucleic Acids Res. 2004, 32, 1792-1797. [CrossRef]

29. Gouy, M.; Guindon, S.; Gascuel, O. SeaView version 4: A multiplatform graphical user interface for sequence alignment and phylogenetic tree building. Mol. Biol. Evol. 2010, 27, 221-224. [CrossRef]

30. Maddison, W.P.; Maddison, D.R. Mesquite: A Modular System for Evolutionary Analysis. Version 3.61. 2019. Available online: http://www.mesquiteproject.org (accessed on 20 July 2020).

31. Darriba, D.; Taboada, G.L.; Doallo, R.; Posada, D. jModelTest 2: More models, new heuristics and parallel computing. Nat. Methods 2012, 9, 772. [CrossRef]

32. Ronquist, F.; Teslenko, M.; Van Der Mark, P.; Ayres, D.L.; Darling, A.; Höhna, S.; Larget, B.; Liu, L.; Suchard, M.A.; Huelsenbeck, J.P. MrBayes 3.2: Efficient Bayesian phylogenetic inference and model choice across a large model space. Syst. Biol. 2012, 61, 539-542. [CrossRef]

33. Felsenstein, J. Confidence limits on phylogenies: An approach using the bootstrap. Evolution 1985, 39, 783-791. Available online: https://www.jstor.org/stable/2408678 (accessed on 18 September 2020). [CrossRef]

34. Rambut, A. FigTree-Tree Figure Drawing Tool Version v.1.4.3; Institute of Evolutionary Biology, University of Edinburgh: Edinburgh. 2016. Available online: http://tree.bio.ed.ac.uk/software/figtree/ (accessed on 18 September 2020).

35. Rambaut, A.; Drummond, A.J.; Xie, D.; Baele, G.; Suchard, M.A. Posterior summarisation in Bayesian phylogenetics using Tracer 1.7. Syst. Biol. 2018, 67, 901-904. [CrossRef]

36. Mayr, E. Animal Species and Evolution; Harvard University Press: Cambridge, UK, 1963.

37. Dobzhansky, T. Genetics of the Evolutionary Process; Columbia University Press: New York, NY, USA, 1970.

38. Costa, J.; Almeida, C.E.; Dujardin, J.P.; Beard, C.B. Crossing Experiments Detect Genetic Incompatibility among Populations of Triatoma Braziliensis Neiva, 1911 (Heteroptera, Reduviidae, Triatominae). Mem. Inst. Oswaldo Cruz 2003, 98, 637-639. [CrossRef]

39. Mendonça, V.J.; Alevi, K.C.C.; Pinotti, H.; Gurgel-Gonçalves, R.; Pita, S.; Guerra, A.L.; Panzera, F.; Araújo, R.F.; Azeredo-Oliveira, M.T.V.; Rosa, J.A. Revalidation of Triatoma bahiensis Sherlock \& Serafim, 1967 (Hemiptera: Reduviidae) and phylogeny of the T. Braziliensis species complex. Zootaxa 2016, 4107, 239-254. [CrossRef] [PubMed]

40. Dujardin, J.P.; Schofield, C.J.; Panzera, F. Los vectores de la enfermedad de Chagas; Académie Royale des Sciences D'Outre-Mer: Bruxelles, Belgium, 2002; 189p.

41. Galvão, C.; Carcavallo, R.U.; Rocha, D.S.; Jurberg, J. A checklist of the current valid species of the subfamily Triatominae Jeannel, 1919 (Hemiptera, Reduviidae) and their geographical distribution, with nomenclatural and taxonomic notes. Zootaxa 2003, 202, 1-36. [CrossRef]

42. QGIS Geographic Information System. Available online: http://qgis.org (accessed on 19 September 2020).

43. Instituto Geográfico Nacional. Available online: https://www.ign.gob.ar/NuestrasActividades/InformacionGeoespacial/ CapasSIG (accessed on 19 September 2020).

44. Ramos, L.J.; Souza, J.L.; Souza, C.R.; Oliveira, J.; Rosa, J.A.; Camargo, L.M.A.; Cunha, R.M.; Meneguetti, D.U.O. First report of Triatoma sordida Stål, 1859 (Hemiptera, Reduviidae, Triatominae) in the State of Acre and Brazilian Western Amazon. Rev. Soc. Bras. Med. Trop. 2018, 51, 77-79. [CrossRef] [PubMed] 
45. Rodrigues, J.M.S.; Moreira, F.F.F.; Deckert, J.; Galvão, C. List of the type specimens of Triatominae (Hemiptera: Heteroptera: Reduviidae) in the Hemimetabola Collection of the Museum für Naturkunde, Berlin. Zootaxa 2020, 4809, 329-348. [CrossRef] [PubMed]

46. Bardella, V.B.; Pita, S.; Vanzela, A.L.L.; Galvão, C.; Panzera, F. Heterochromatin base pair composition and diversification in holocentric chromosomes of kissing bugs (Hemiptera, Reduviidae). Mem. Inst. Oswaldo Cruz 2016, 111, 614-662. [CrossRef]

47. García, B.A.; Moriyama, E.N.; Powell, J.R. Mitochondrial DNA sequences of triatomines (Hemiptera: Reduviidae): Phylogenetic relationships. J. Med. Entomol. 2001, 38, 675-683. [CrossRef]

48. Belintani, T.; Oliveira, J.; Pinotti, H.; Silva, L.A.; Alevi, K.C.C.; Galvão, C.; Rosa, J.A. Phylogenetic and phenotypic relationships of the Triatoma sordida subcomplex (Hemiptera: Reduviidae: Triatominae). Acta Trop. 2020, 212, 105679. [CrossRef]

49. Madeira, F.F.; Delgado, L.M.G.; Bittinelli, I.F.; Sartori, R.Q.; Oliveira, J.; Rosa, J.A.; Azeredo-Oliveira, M.T.V.; Alevi, K.C.C. Revisiting the genetic variability of the Brazilian peridomestic populations of the Chagas disease vector Triatoma sordida (Stål, 1859) (Hemiptera, Triatominae). Infect. Genet. Evol. 2020, 85, 104568. [CrossRef]

50. Oscherov, E.B.; Damborsky, M.P.; Bar, M.E. Características biológicas de Triatoma sordida (Heteroptera, Reduviidae): Ciclo de vida. Rev. Soc. Eniomol. Argent. 1998, 57, 13-17. Available online: https://www.biotaxa.org/RSEA/article/ download/33689/29858 (accessed on 18 September 2020).

51. Souza, J.M.P.; Rodrigues, V.L.C.C.; Rocha e Silva, E.O. Triatoma sordida: Considerações sobre o tempo de vida das formas adultas e sobre a oviposição das fêmeas. Rev. Saúde Públ. 1978, 12, 291-296. [CrossRef]

52. Pinto, C.F. Fatos curiosos sobre a biologia do Triatoma sordida (Nota prévia). Rev. Soc. Bras. Med. 1949, 6, 305.

53. Schofield, C.J.; Lehane, M.J.; McEwan, P.; Catala, S.S.; Gorla, D.E. Dispersive flight by Triatoma sordida. Trans. R. Soc. Trop. Med. Hyg. 1991, 85, 676-678. [CrossRef]

54. Bar, M.E.; Oscherov, E.B.; Damborsky, M.P.; Varela, M.E.; Mizdraji, G.; Porcel, E. Triatomismo del Departamento San Luis del Palmar de la Provincia de Corrientes, Argentina. Medicina 1992, 52, 193-201. [PubMed]

55. Bar, M.E.; Oscherov, E.B.; Damborsky, M.P. Presencia de Triatoma sordida Stål, 1859 en ecótopos urbanos de la ciudad de Corrientes, Argentina. Rev. Saúde Públ. 1993, 27, 117-122. [CrossRef]

56. Bar, M.E.; Oscherov, E.B.; Damborsky, M.P.; Porcel, E.A.; Alvarez, B.M. Population interactions between Triatoma infestans and Triatoma sordida. Rev. Saúde Públ. 1994, 28, 59-68. [CrossRef]

57. Bar, M.E.; Oscherov, E.B.; Avalos, G.; Damborsky, M.P.; Alvarez, B.M. Infección natural de Triatoma sordida por Trypanosoma cruzi en ecótopos silvestres de la provincia de Corrientes, Argentina. In Resúmenes, 5 ta. Jornada de Biología, Instituto de Investigaciones en Ciencias de la Salud; Universidad Nacional de Asunción: Asunción, Paraguay, 1996; pp. 32-33.

58. Bar, M.E.; Damborsky, M.P.; Oscherov, E.B.; Alvarez, B.M.; Mizdraji, G.; Avalos, G. Infestación domiciliaria por triatominos y seroprevalencia humana en el Departamento Empedrado, Corrientes, Argentina. C. Saúde Pública 1997, 13, 305-312. [CrossRef]

59. Bar, M.E.; Wisnievsky-Colli, C. Triatoma sordida Stål 1859 (Hemiptera, Reduviidae: Triatominae) in palms of northeastern Argentina. Mem. Inst. Oswaldo Cruz 2001, 96, 895-899. [CrossRef] [PubMed]

60. Bar, M.E. Estructura y dinámica poblacional de Triatoma sordida Stål 1859 en una comunidad de Butia yatay en Argentina. Bol. Malariol. Salud Ambient. 2006, 46, 21-30. Available online: http://ve.scielo.org/scielo.php? script=sci_arttext\&pid=S1690-46482006000100003\&lng=es\&nrm=iso (accessed on 18 September 2020).

61. Gorla, D.E.; Jurberg, J.; Catala, S.S.; Schofield, C.J. Systematics of Triatoma sordida, T. guasayana and T. patagonica (Hemiptera, Reduviidae). Mem. Inst. Oswaldo Cruz 1993, 88, 379-385. [CrossRef]

62. McEwen, P.K.; Lehane, M.J. Factors influencing flight initiation in the triatomine bug Triatoma sordida (Hemiptera: Reduviidae). Insect Sci. Appl. 1993, 14, 461-464. [CrossRef]

63. Wisnivesky-Colli, C.; Gürtler, R.E.; Solarz, N.D.; Schweigmann, N.J.; Silvia, M.; Pietrokovsky, S.M.; Alberti, A.; Flo, J. Dispersive flight and house invasion by Triatoma guasayana and Triatoma sordida in Argentina. Mem. Inst. Oswaldo Cruz 1993, 88, 27-32. [CrossRef] [PubMed]

64. Wisnivesky-Colli, C.; Pietrokovsky, S.; Bottazzi, V.; Haedo, A.; Solarz, N.; Schweigmann, N.; Canale, D.; Reyes, O.R. Laboratory comparison of feeding success among Triatoma infestans, T. guasayana, and T. sordida (Hemiptera: Reduviidae). J. Med. Entomol. 1995, 32, 583-587. [CrossRef] [PubMed] 
65. Crocco, L.B.; Catalá, S.S. Feeding and defaecation patterns in Triatoma sordida. Mem. Inst. Oswaldo Cruz 1996, 91, 409-413. [CrossRef] [PubMed]

66. Crocco, L.; Catalá, S. Host preferences of Triatoma sordida. Ann. Trop. Med. Parasitol. 1997, 91, 927-930. [CrossRef] [PubMed]

67. Oscherov, E.B.; Damborsky, M.P.; Bar, M.E.; Porcel, E. Population statistics of Triatoma sordida Stäl 1859 (Hemiptera: Reduviidae) in experimental conditions. Rev. Saúde Públ. 1996, 30, 438-443. [CrossRef] [PubMed]

68. Oscherov, E.B.; Damborsky, M.P.; Bar, M.E.; Avalos, G.; Alvarez, B.M.; Presman, H.; Wisnivesky-Colli, C. Interactions between Triatoma infestans and Triatoma sordida (Hemiptera: Reduviidae) in artificial ecotopes: Population growth and age structure. J. Med. Entomol. 2001, 38, 214-217. [CrossRef]

69. Pietrokovsky, S.; Bottazzi, V.; Schweigmann, N.; Haedo, A.; Wisnivesky-Colli, C. Comparison of the blood meal size among Triatoma infestans, T. guasayana and T. sordida (Hemiptera: Reduviidae) of Argentina under laboratory conditions. Mem. Inst. Oswaldo Cruz 1996, 91, 241-242. [CrossRef]

70. Schweigmann, N.J.; Pietrokovsky, S.; Conti, O.; Escosteguy, M.; Bottazzi, V.; Solarz, N.; Wisnivesky-Colli, C. Infection of Triatoma guasayana, Triatoma sordida and Triatoma infestans by Trypanosoma cruzi from a naturally infected opossum. Mem. Inst. Oswaldo Cruz 1997, 92, 151-152. [CrossRef]

71. Rebagliati, P.; Papeschi, A.G.; Mola, L.M.; Pietrokovsky, S.; Gajate, P.; Botazzi, V.; Wisnivesky-Colli, C. Comparative meiotic studies in Triatoma sordida (Stål) and T. guasayana Wygodzinsky \& Abalos (Reduviidae, Heteroptera). Mem. Inst. Oswaldo Cruz 1998, 93, 309-315. [CrossRef]

72. Maffey, L.; Cardinal, M.V.; Ordonez-Krasnowski, P.C.; Lanati, L.A.; Lauricella, M.A.; Schijman, A.G.; Gürtler, R.E. Direct molecular identification of Trypanosoma cruzi discrete typing units in domestic and peridomestic Triatoma infestans, and Triatoma sordida from the Argentine Chaco. Parasitology 2012, 139, 1570-1579. [CrossRef]

73. Macchiaverna, N.P.; Gaspe, M.S.; Enriquez, G.F.; Tomassone, L.; Gürtler, R.E.; Cardinal, M.V. Trypanosoma cruzi infection in Triatoma sordida before and after community-wide residual insecticide spraying in the Argentinean Chaco. Acta Trop. 2015, 143, 97-102. [CrossRef] [PubMed]

74. Pessoa, G.C.A.; Sousa, T.N.; Sonoda, I.V.; Diotaiuti, L. Assessing the mitochondrial DNA diversity of the chagas disease vector Triatoma sordida (Hemiptera: Reduviidae). Mem. Inst. Oswaldo Cruz 2016, 111, 322-329. [CrossRef] [PubMed]

75. Rodríguez-Planes, L.I.; Gaspe, M.S.; Enriquez, G.F.; Gürtler, R.E. Habitat-specific occupancy and a metapopulation model of Triatoma sordida (Hemiptera: Reduviidae), a secondary vector of Chagas disease, in northeastern Argentina. J. Med. Entomol. 2018, 55, 370-381. [CrossRef] [PubMed]

76. Pita, S.; Lorite, P.; Nattero, J.; Galvão, C.; Alevi, K.C.C.; Teves, S.C.; Azeredo-Oliveira, M.T.V.; Panzera, F. New arrangements taxon several species subcomplexes of Triatoma genus based on the chromosomal position of ribosomal genes (Hemiptera -Triatominae). Infect. Genet. Evol. 2016, 43, 225-231. [CrossRef]

77. Carcavallo, R.U.; Jurberg, J.; Lent, H.; Noireau, F.; Galvão, C. Phylogeny of the Triatominae (Hemiptera Reduviidae). Proposals for taxonomic arrangements. Entomol. Vectores 2000, 7, 1-99. Available online: https://horizon. documentation.ird.fr/exl-doc/pleins_textes/divers12-11/010024157.pdf (accessed on 18 September 2020).

78. Schofield, C.J.; Galvão, C. Classification, evolution and species groups within the Triatominae. Acta Trop. 2009, 110, 88-100. [CrossRef]

79. Dorn, P.L.; Justi, S.A.; Dale, C.; Stevens, L.; Galvão, C.; Lima-Cordón, R.; Monroy, C. Description of Triatoma mopan sp. n. from a cave in Belize (Hemiptera, Reduviidae, Triatominae). Zookeys 2018, 775, 69-95. [CrossRef]

80. Lima-Cordón, R.A.; Monroy, M.C.; Stevens, L.; Rodas, A.; Rodas, G.A.; Dorn, P.L.; Justi, A.S. Description of Triatoma huehuetenanguensis sp. n., a potential Chagas disease vector (Hemiptera, Reduviidae, Triatominae). ZooKeys 2019, 820, 51-70. [CrossRef]

81. Schreiber, G.; Pinho, A.C.; Parentoni, R.; Salgado, A.A.; Godoi, T.L., Jr. Cytogenetics of Triatominae: II Spermatogenesis in hybrid between Triatoma infestans and Triatoma pseudomaculata (Hemiptera, Reduviidae). Rev. Bras. Biol. 1974, 31, 1-9. Available online: https://pubmed.ncbi.nlm.nih.gov/4618618/ (accessed on 18 September 2020).

82. Pérez, R.; Hérnandez, M.; Quintero, O.; Scvortzoff, E.; Canale, D.; Méndez, L.; Cohanoff, C.; Martino, M.; Panzera, F. Cytogenetic analysis of experimental hybrids in species of Triatominae (Hemiptera-Reduviidae). Genetica 2005, 125, 261-270. [CrossRef] 
83. Martínez-Ibarra, J.A.; Grant-Guillén, Y.; Delgadillo-Aceves, I.N.; Zumaya-Estrada, F.A.; Rocha-Chávez, G.; Salazarschettino, P.M.; Alejandre-Aguilar, R.; Villalobos, G.; Nogueda-Torres, B. Biological and genetic aspects of crosses between phylogenetically close species of Mexican Triatomines (Hemiptera: Reduviidae). J. Med. Entomol. 2011, 48, 705-707. [CrossRef]

84. Díaz, S.; Panzera, F.; Jaramillo-O, N.; Pérez, R.; Fernández, R.; Vallejo, G.; Saldaña, A.; Calzada, J.E.; Triana, O.; Gómez-Palácio, A. Genetic, Cytogenetic and Morphological Trends in the Evolution of the Rhodnius (Triatominae: Rhodniini) Trans-Andean Group. PLoS ONE 2014, 9, e87493. [CrossRef]

85. Mendonça, V.J.; Alevi, K.C.C.; Medeiros, L.M.O.; Nascimento, J.D.; Azeredo-Oliveira, M.T.V.; Rosa, J.A. Cytogenetic and morphologic approaches of hybrids from experimental crosses between Triatoma lenti Sherlock \& Serafim, 1967 and T. sherlocki Papa et al., 2002 (Hemiptera: Reduviidae). Infect. Genet. Evol. 2014, 26, 123-131. [CrossRef] [PubMed]

86. Campos-Soto, R.; Panzera, F.; Pita, S.; Lages, C.; Solari, A.; Botto-Mahan, C. Experimental crosses between Mepraia gajardoi and M. spinolai and hybrid chromosome analyses reveal the occurrence of several isolation mechanisms. Infect. Genet. Evol. 2016, 45, 205-212. [CrossRef] [PubMed]

87. Alevi, K.C.C.; Pinotti, H.; Araújo, R.F.; Azeredo-Oliveira, M.T.V.; Rosa, J.A.; Mendonça, V.J. Hybrid colapse confirm the specific status of Triatoma bahiensis Sherlock and Serafim, 1967 (Hemiptera, Triatominae). Am. J. Trop. Med. Hyg. 2018, 98, 475-477. [CrossRef] [PubMed]

88. Villacís, A.G.; Dujardin, J.P.; Panzera, F.; Yumiseva, C.A.; Pita, S.; Santillán-Guayasamín, S.; Orozco, M.I.; Mosquera, K.D.; Grijalva, M.J. Chagas vectors Panstrongylus chinai (Del Ponte, 1929) and Panstrongylus howardi (Neiva, 1911): Chromatic forms or true species? Parasit. Vectors 2020, 13, 226. [CrossRef] [PubMed]

89. Castro, G.B.; Machado, E.M.M.; Borges, E.C.; Lorosa, E.S.; Andrade, R.E.; Diotaiuti, L.; Azeredo, B.V.M. Trypanosoma cruzi Peridomiciliar Transmission by Triatoma sordida in the Municipality of Patis, Gerais State, Brazil. Mem. Inst. Oswaldo Cruz 1997, 92, 434. [CrossRef]

90. Lorosa, E.S.; Andrade, R.E.; Santos, S.M.; Pereira, C.A. Estudo da infecção natural e da fonte alimentar do Triatoma sordida (Stal, 1859), (Hemiptera -Reduviidae) na região norte de Minas Gerais, Brazil, através da reação de precipitina. Entomol. Vectores 1998, 5, 13-22.

91. Brenière, S.F.; Aliaga, C.; Waleckx, E.; Buitrago, R.; Salas, R.; Barnabé, C.; Tybayrenc, M.; Noireau, F. Genetic characterization of DTUs in wild Triatoma infestans from Bolivia: Predominance of TcI. PLoS Negl. Trop. Dis. 2012, 6, e1650. [CrossRef] [PubMed]

92. Rossi, J.C.N.; Duarte, E.C.; Gurgel-Gonçalves, R. Factors associated with the occurrence of Triatoma sordida (Hemiptera: Reduviidae) in rural localities of Central-West Brazil. Mem. Inst. Oswaldo Cruz 2015, 110, 192-200. [CrossRef] [PubMed]

93. Pickenheyn, J.; Guimarães, R.B.; Lima, S.C.; Curto, S. Processo de urbanização da Doença de Chagas na Argentina e no Brazil. Hygeia 2009, 4, 58-69. Available online: http://www.seer.ufu.br/index.php/hygeia/ article/view/16920 (accessed on 18 September 2020).

Publisher's Note: MDPI stays neutral with regard to jurisdictional claims in published maps and institutional affiliations.

(C) 2020 by the authors. Licensee MDPI, Basel, Switzerland. This article is an open access article distributed under the terms and conditions of the Creative Commons Attribution (CC BY) license (http://creativecommons.org/licenses/by/4.0/). 